\title{
Slika Rodika izpred dveh stoletij: vidno, navidezno in hipoteze med zgodovino in ljudskim izročilom
}

\author{
Aleksander Panjek \\ Univerza na Primorskem \\ aleksander.panjek@fhs.ipr.si
}

\section{Uvod}

S tem prispevkom o zgodovini primorskega podeželja se osredotočam na vas Rodik, ki je doslej pritegnila več arheološke in etnološke znanstvene ter strokovne pozornosti kot zgodovinskih raziskav. ${ }^{1}$ Tudi pričujoča zgodovinska slika ni vseobsegajoča, saj je pogled usmerjen predvsem $v$ gospodarstvo, družbo in okolje ter v kratko obdobje, a obenem v preverjanje lokalnega ustnega izročila o nastanku in strukturi naselja skozi daljše obdobje. Osrednjo podlago tvorijo podatki in informacije iz Franciscejskega katastra, ki jih dopolnjujem $\mathrm{z}$ znanstveno in s strokovno literaturo.

Franciscejski kataster je že dolgo znan in cenjen vir za raziskovanje, posebej med zgodovinarji in geografi, a tudi etnologi (Baš 1952; Natek 1979; Ribnikar 1982; Golec 2010). Odlikuje ga izjemno bogastvo informacij, ki prvič v zgodovini našega prostora omogočajo tako sistematičen in detajlni vpogled, tj. do ravni posamezne njive in hiše, ter obenem širši pregled stanja, in sicer na osnovi standardiziranih podatkov v kartografski, besedilni in številčni obliki. Zaradi tega je uporaben in uporabljan tako za študije na mikroravni posameznih naselij kot za obsežnejše regionalne analize. ${ }^{2}$ Po Blazniku (1980, 120) je Franciscejski kataster »eden osnovnih virov za študij gospodarske zgodovine našega podeželja«. Njegova dragocenost je tudi v tem, da je nastal v obdobju prehoda iz predindustrijske družbe $\mathrm{v}$ dobo industrializacije, tako da nam predstavlja sliko stanja ob koncu dolgega srednje- in novoveškega zgodovinskega razvoja ter hkrati izhodiščne

${ }^{1}$ Za etnologijo Hrobat Virloget (2005; 2010a; b); za arheologijo Slapšak (2003) s tam navedeno literaturo; strokovni monografiji sta Pregelj (1997) in Peršolja (2009).

${ }^{2}$ Kot primere novejših študij lokalnega obsega glej Baš (2008), Kačičnik Gabrič (2004), Vodopivec (2011) in Ratkajec (2014), širše zastavljenih analiz za Primorsko pa Panjek (2015b) in Kolega (2018), za Koroško Drobesch (2013). V vseh je navedena dodatna literatura. 
razmere na začetku pronicanja modernih gospodarskih in družbenih pa tudi kulturnih sprememb.

$\mathrm{V}$ primeru Rodika imamo to srečo, da je ohranjenega veliko gradiva, ki pripada spisovnemu delu Franciscejskega katastra. Izmed njegovih opisnih delov razpolagamo tako $\mathrm{z}$ obrazcem cenilnega operata $\mathrm{v}$ obliki vprašalnika, ki je zgodnejšega nastanka (1819), kot $s$ kasnejšim v obliki poročila (1830), ki ju bomo uporabili za okvirni oris (AS T, CF, SE, 619/1, Q-CSO S/4 ter 619/2, Oec S/5). Informacije, ki jih je mogoče povzeti iz obeh dokumentov, se razlikujejo že zaradi njunega drugačnega nastanka. Prvi je zapis odzivov vaških mož »župe Rodik«, in sicer župana Antona Šumana ter predstavnikov zbora skupnosti (Gemeinde Ausschuss Männer) Martina Čebohina in Jožefa Raceta, na standardni vprašalnik, pri čemer je mogoče zaznati njihovo težnjo po izpostavljanju pomanjkljivosti naravnih virov in skromnosti kmetijstva, a obenem po poudarjanju vidikov, ki so se krajanom zdeli posebej omembe vredni.

Druga vrsta dokumenta (uradno poročilo) pa teži k objektivnosti in sloni na številčnih meritvah ter drugih kolikor mogoče natančnih podatkih. Poleg teh bomo uporabili še dva pisna dokumenta iz Franciscejskega katastra, in sicer seznama posestnikov (zapisnika) stavbnih parcel in kmetijskih zemljišč (1820). ${ }^{3}$ Pisne vire bomo integrirali z informacijami, ki jih je mogoče razbrati iz katastrskih kart.

Pričujoči analiza in interpretacija nikakor ne izčrpata vseh možnih razsežnosti povednosti podatkov in informacij, ki jih nudi Franciscejski kataster. To niti ni namen te razprave, $s$ katero nameravam na eni strani podati zaokroženo sliko izbranih gospodarskih, socialnih in okoljskih vidikov neke skupnosti na pragu modernizacije in s tem pokazati potencial povednosti Franciscejskega katastra kot zgodovinskega vira, na drugi pa opozoriti tudi na potencialno zavajajoči vtis, ki nam ga daje. V drugem delu se razprava osredotoča na vprašanje, ali je v posestni strukturi zemljišč in razporejenosti bivališč v Rodiku mogoče zaslediti vzorce, ki bi lahko predstavljali materialno sled vaškega ljudskega izročila o nastanku naselja in o notranjih delitvah skupnosti, kakršne izpričujeta etnološka in folklorna literatura. Preveriti želim, ali je izsledke etnoloških raziskav mogoče potrditi $z$ rezultati zgodovinske metode, ali so eni in drugi skladni ter, nenazadnje, kaj lahko zgodovinska obravnava prispeva k poznavanju skupnosti in razumevanju njenega izročila.

\footnotetext{
${ }^{3}$ A S T, CF, SE, 618/2, P G P ter 618/4, P B P. V vseh primerih sledimo izvirnim zapisom v kata-
} stru in ne upoštevamo kasnejših popravkov (1834 in 1836). 


\section{O kmetijstvu in prehrani onkraj prvega vtisa zaostalosti}

Rodiški župan Anton Šuman ter predstavnika skupnosti Martin Čebohin in Jožef Race so v odgovorih na vprašalnik, datiran z 19. junijem 1819, zatrjevali, da na njivah niso imeli nobenega pridelka posebne kakovosti, $v$ vrtovih pa naj ne bi pridelovali nič posebnega ali omembe vrednega. Od sadnega drevja so na vasi gojili le nekaj češpelj, a jih ni bilo veliko. Tudi njihovo vino, poimenovano "Vremščinec«, je bilo "najslabše kakovosti in pogosto sploh ni pitno«. Premogli so nekaj malega vinogradov, trt na njivah niso sadili.

Navedli so, da v poljedelstvu sledijo "nekemu natriletnemu načinu obdelovanja « brez prahe in da njive gnojijo na tri leta. Prahe naj ne bi uporabljali zaradi tega, ker če se njivo pusti v prahi, se plevel "preveč razmahne«. Ker pa je opuščanje prahe ena temeljnih značilnosti modernizacije v kmetijstvu, velja pripomniti, da neprekinjeni kolobar pomeni boljšo izrabo in intenzivnejše obdelovanje zemlje, kar poveča skupni pridelek. A ne samo to: iz poročila 1830 izhaja, da $v$ resnici niso uporabljali enostavnega natriletnega kolobarja brez prahe, temveč kompleksna dolgoletna zaporedja posevkov, katerih niz je trajal 5, 15 ali celo 17 let, odvisno od kakovosti zemlje, po principu boljša zemlja - daljši niz. Izjemo so predstavljale njive najboljše kakovosti (1. razreda), kjer je bil kolobar le dveleten in neprekinjen ter zelo intenziven, na dve leti so zemljo tudi gnojili: prvo leto so na pognojeni zemlji pridelovali zelje, drugo leto pa rž in nato še ajdo. $V$ daljših nizih pa so si v zapletenih zaporedjih sledile različne poljščine: poleg že omenjenih (rž, ajda, zelje) še pšenica, ječmen, fižol, repa, koruza in krompir (preglednica 1 ). Medtem ko koruza na rodiških njivah na začetku 19. stoletja ne more biti večje presenečenje, saj se je marsikje na Primorskem med pridelki pojavila najkasneje $\mathrm{v}$ teku 18. stoletja, je smiselno izpostaviti prisotnost krompirja.

Še posebej zanimivo pa je to, da sta obe »novi« kulturni rastlini dotlej že zavzeli pomembno vlogo $\mathrm{v}$ prehrani, zaradi česar moremo reči, da so bili v Rodiku povsem $v$ skladu z najnovejšimi trendi na tem področju. Koruza je v prehrani že imela tolikšno vlogo, da je niso pridelovali dovolj za lastne potrebe, zato so jo dodatno kupovali v Trstu. Zelje, krompir in repa pa so bili presežni pridelki, ki so jih prodajali deloma v okolici in delno $\mathrm{v}$ Trstu, kjer so Rodičani z iztržkom poleg dodatne koruze nabavljali še "sol, olje in druge kmečkim družinam neobhodno potrebne vrste blaga«. A vrnimo s k hrani, za katero katastrski vir za Rodik navaja, da je taka, kot je opisana v Naklem: "Njihovo običajno prehrano so sestavljali kruh iz mešanice ajde 
Preglednica 1

Zaporedje posevkov na boljši zemlji (2. razreda) v Rodiku (1830)

Opombe Naslovi stolpcev: (1) skupno zaporedje (leto), (2) obdobje, (3) leto znotraj obdobja,

(4) gnojenje,

(5) vrsta kulture.

\begin{tabular}{lllll}
\hline$(1)$ & $(2)$ & $(3)$ & $(4)$ & $(5)$ \\
\hline 1. & I. & 1. & da & zelje \\
2. & & 2. & ne & rž, ajda \\
\hline 3. & II. & 1. & da & rž, ajda \\
4. & & 2. & ne & koruza, fižol \\
5. & & 3. & ne & koruza, fižol \\
6. & & 4. & ne & pšenica \\
7. & & 5. & ne & oves \\
\hline 8. & III. & 1. & da & krompir \\
9. & & 2. & ne & rž, ajda \\
10. & & 3. & ne & oves \\
\hline 11. & IV. & 1. & da & zelje \\
12. & & 2. & ne & rž, ajda \\
\hline 13. & V. & 1. & da & rž, ajda \\
14. & & 2. & ne & koruza, fižol \\
15. & & 3. & ne & koruza, fižol \\
16. & & 4. & ne & pšenica \\
17. & & 5. & ne & oves \\
\hline
\end{tabular}

in koruze, mineštra iz sveže ali kisle repe, nekaj stročnic, zelenjava z vrta in polenta."V Naklem svojega vina niso pridelovali, zaradi česar "so ga bili prisiljeni kupovati $\mathrm{v}$ zelo majhnih količinah naenkrat, in dobro razvodenelega; pogosto uporabljajo tudi kis z vodo« (AS T, CF, SE, 468/2, Oec S/5). No, v Rodiku so imeli svoje vino. A k temu, da je bila v Rodiku »običajna prehrana taka kot $v$ Naklem, je treba dodati še krompir, katerega ti kmetje porabijo zelo veliko«.

Da so bili v Naklem prisiljeni kupovati vino, deluje kot potrditev že znane vloge vina kot sestavnega dela prehrane na Primorskem. Tudi prvo mesto kruha v navedenem nizu vrst hrane zrcali njegovo osnovno mesto v kmečki prehrani, če pomislimo, da so pomanjkanje kruha in na zelenjavi temelječo prehrano stoletje poprej kraški kmetje enačili s človeka nevrednim načinom prehranjevanja (Panjek 2018a). Sicer pa je v tem okviru mogoče zaslediti tudi vsaj dva elementa modernejših vrst hrane, saj sta pomembno vlogo $\mathrm{v}$ rodiškem jedilniku $\mathrm{z}$ začetka 19. stoletja zasedala tako koruza ( $\mathrm{v}$ kruhu in v obliki polente) kot izrecno poudarjena velika količina krompirja. Zlasti v slednjem je zaznati modernost za takratne razmere, posebej za Primorsko, kjer je krompir zaostajal za koruzo, ki je bila sestavni del jedilnika kraških kmetov vsaj od sredine 18. stoletja. V notranjosti slovenskih dežel 
pa je bilo stanje obratno, saj "se je krompir na Kranjskem v drugi polovici 18. stoletja povsem uveljavil in postal skoraj glavna hrana podeželskega in mestnega prebivalstva «, pri čemer pa koruzi »dolgo ni uspelo, da bi zavzela pomembnejše mesto med posevki in je ponekod, zlasti v prvi polovici 19. stoletja, zaostajala daleč za krompirjem" (Britovšek 1958/1959, 127). V Rodiku so torej najkasneje do leta 1830 usvojili obe »novi« kulturni rastlini, to je "primorsko« (koruzo) in »kranjsko« (krompir).

Kljub vsemu pa so $v$ navedenem načinu prehranjevanja povsem odsotni proteini, kar je mogoče interpretirati kot preplet spozabe zapisovalcev in dejansko skromnega obsega jedi ter sestavin živalskega izvora, kakor ga v 18. stoletju poznamo tudi drugod po Krasu in po navedbah Franciscejskega katastra za druge vasi, kjer nastopata vsaj sir in nekaj svinjine v joti ob praznikih. K taki hipotezi, to je o obstoju sestavin živalskega izvora vsaj občasno in vsekakor v skromnem obsegu, napeljuje živina, popisana v Rodiku. Tu najdemo tako ovce (sir) kot prašiče (slanina). Kot potrditev lahko upoštevamo določila "pogodbe« s prvim župnikom v Rodiku (M. J. Muha, 1786-1820), po kateri se je vsaka družina zavezala, da mu bo jeseni izročila "zaboj zelja, repe itd." ter »slanino in koline«. $S$ kasnejšim dogovorom (1837) so bili Rodičani župniku dodatno dolžni »8 funtov sira« (Zupet 1997, 77; Peršolja in Pregelj 1997, 111).

\section{O navidezno neobstoječih naravnih virih}

V vprašalniku iz leta 1819 so predstavniki rodiške skupnosti trdili, da nimajo gozdov, temveč samo nekaj grmovja oziroma goščave. Na travnikih je bilo najti nekaj hrastov, katerih les so uporabljali za domače potrebe (orodje, kurjavo). Povsem v skladu s splošnim takratnim mnenjem kraških kmetov (Panjek 2015b, 92) so tudi v Rodiku izrazili stališče, da hrasti za pridobivanje lesa $\mathrm{v}$ gradbene namene postanejo primerni šele pri starosti od 100 do 200 let. $V$ resnici so $k$ Rodiku sodili tudi gozdovi na pobočju hriba za vasjo, ki pa niso bili na kraških tleh, temveč na brkinskih, lapornatih. Tako je iz poročila razvidno, da so se na območju katastrske občine nahajali čisti bukovi gozdovi ali pa so bila gozdnata tla poraščena v mešanem sestoju redkejših bukev in hrastov ter jesenov, pomešanih z gabri, leskami in drugimi vrstami drevja. Nekaj podobnega kot za gozdne velja tudi za vodne vire, v smislu, da je bilo dejansko stanje nekoliko drugačno od vtisa ob prvem branju.

$\mathrm{V}$ primeru vode sta si vprašalnik in poročilo operata skladnejša, saj se v prvem trdi, da v Rodiku »ni potokov, ribnikov, jezer ali močvirij«, v drugem pa, da »na celotnem občinskem območju ni nobene reke, potoka, hudour- 
nika, jezer ali ribnikov z vodo«, a s pojasnilom, da zraven vasi »obstajajo razni mali izviri, iz katerih priteka bistra in zdrava voda, ki jo uporabljajo« vaščani. Vendar pogled na katastrske karte kaže nekoliko drugače: sredi njiv in travnikov $\mathrm{v}$ podolju severno od vasi poteka jasno zarisana modra struga $\mathrm{z}$ nekaj stranskimi rokavi in manjšim zajetjem, $\mathrm{v}$ katerega pritekata dva manjša vodotoka; v bližini je še kal. Posebej zanimiva so ledinska imena na tem območju. Ob kalu je zapisano ime »Per Kalush", vzdolž navedene struge pa beremo "Na Mlaka«, »Pod Jeserom« in še »Jeseron«. Jezera sicer ni videti, je pa videti, da parcelacija poteka v obliki, ki spominja na obliko jezera, ki ga očitno ni bilo več. Nekoliko vzhodneje, vzporedno $\mathrm{z}$ navedeno večjo strugo, je zarisana druga, tanka struga s pripisom "Pottok Leszishino " ob ledinskem imenu »Pod Liscizno « (Lisično), ta potok pa ima štiri manjše pritoke. Drugje najdemo ledinski imeni »Pod Wodiza« (na skrajnem severovzhodnem robu katastrske občine) in "Pod Stirna" (na skrajnem jugozahodnem robu), kjer pa voda ni vidno vrisana. Na južnem koncu pod vasjo srečamo še ledinski imeni »Per Kale« in »Pod Kallem Dollina", vode pa ni vrisane. Tik ob vasi Rodik na severni strani najdemo ledinsko ime »Per Kalushe«, kar je sicer območje, ki smo ga $z$ istim imenom (»Per Kalush«) že navedli na drugem odseku karte. Prav sredi vasi se najdeta še dva s krajšim vodotokom med seboj povezana kala oziroma vodni zajetji, iz drugega od katerih teče skozi vas ob cesti tanka struga potoka, ki se nato prekine in izgubi. Izpod pobočja nad vasjo pa izvirata dva potočka. Ta se stekata v prvo omenjeno, večjo strugo oziroma njeno vodno zajetje. Nazadnje na Kozini zasledimo še zadnji kal. Na skrajnem jugovzhodnem koncu katastrske občine krajši odsek njene meje teče vzdolž »Globokega Potoka«, tam je zarisano tudi vodno zajetje, ledinsko ime je tu »Mühle Misnik«, torej istoimenski mlin.

V opisu meja k. o. Rodik, ki se začenja v njenem jugozahodnem kotu pri Kozini in poteka $\mathrm{v}$ smeri od zahoda proti vzhodu, se omenjajo sledeče obmejne vode. Prva se nahaja šele blizu jugovzhodnega konca občine, in sicer na mejni točki »Pischeniuz«, sredi vzpona na Čuk (v kraju »NavlachiCzucki«), »kjer izvira ena močvirnata voda«. Kmalu se potek meje preusmeri in sledi toku potoka, imenovanega »Marin Pottok«, ki se nato preimenuje $\mathrm{v}$ »Polaschitza in nadaljuje do sotočja [pri mlinu Misnik Andreja Dujca iz Rodika]Polaschitze in Globokega Potoka«. Od tod se meja obrne v severovzhodno smer in sledi Globokemu potoku do sotočja z drugim, imenovanim "Serabotin Pattok ob vznožju hriba Scalino Berdo«, kjer je tromeja med Rodikom, Brezovico in Artvižami. Naslednji mejni vodotok srečamo šele na nasprotni, severni strani občine Rodik, kjer meja poteka od 
izvira (drugega a istoimenskega) Globokega potoka vzdolž njegove struge »do točke, kjer sreča tok [ali morda drčo, slap: Wasserieß] Potoka pod Lisično, ki priteka z območja občine Rodik« (A S T, C F, SE, 618/1, G B).

Čeprav se je na podlagi vseh teh navedb težko znajti v prostoru, nam ta niz informacij vendarle daje nekaj sporočil. Prvič, območje katastrske občine Rodik je vsaj na dveh koncih mejilo na vodo in je bilo znotraj prepredeno $\mathrm{z}$ vodotoki ter posejano $s$ kali. Drugič, nekateri teh kalov in jezero so do izdelave katastra na začetku 19. stoletja presahnili. Tretjič, Rodik je premogel tudi svoj mlin, sicer na skrajnem koncu svojega teritorija in dokaj daleč od vasi. Temu mlinu oziroma po ljudskem izročilu dvema mlinoma so rekli »Mišnik ali po mlinarju Dujčev mlin« (Peršolja 2009, 479-480). V Franciscejskem katastru je opredeljen kot "podlivni mlin z dvema mlinščicama« (nem. eine unterschlagtige Mühle mit 2 Gängen) in pripisan lastniku Andreju Dujcu.

Dodatno zanimivo pa je to, da ob večkrat omenjeni večji strugi na severni strani katastrske občine, ob kateri so se nahajala ledinska imena z jezerom, in natančneje na mestu, kjer je na katastrski karti vrisano vodno zajetje, stojita dve stavbni parceli. Ena od obeh je v seznamu lastnikov stavbnih parcel poimenovana "Stari mlin«, kar seveda pomeni, da je nekoč tudi tu deloval mlin, in potrjuje sklep, da je bilo $\mathrm{v}$ času nastanka Franciscejskega katastra vode manj kot v bolj oddaljeni preteklosti. Kljub temu pa je možen še nadaljnji sklep, in sicer da je bilo vode vseeno več, kot kažeta zapisa tako v vprašalniku kot v poročilu katastrskega operata (slika 1). Potrditev navedene interpretacije in pojasnilo o tem, kakšne vrste voda so navedene na katastrskih kartah, je najti v seznamu zemljiških parcel, saj imajo mlake in največja struga, kot smo jo doslej poimenovali, svojo katastrsko številko. Tako oštevilčenih vodnih enot je v katastrski občini skupaj devet: tri so v seznamu zemljiških parcel opredeljene kot »lokev v vasi Rodik« (nem. Laach in Dorf Rodig), preostalih šest pa so opredelili kot »lokve in odvodni kanali“ (nem. Lach und Ableitungs Gruben).

Naša, širša, struga, ki se začenja pri zajetju ob »starem mlinu«, je torej odvodni oziroma vodni kanal, vsekakor rezultat umetne regulacije voda na območju, kjer je nekoč ležalo "jezero« (slika 2). O tem, starejšem, mlinu (v Franciscejskem katastru sta kot njegova lastnika navedena Bernechich Anton oziroma Illucig Michail, vulgo Sirg, ležal pa je na območju z ledinskim imenom "Za Loch«) in bližnjem kanalu je mogoče najti omembe tudi v ljudskem izročilu.

Sirkova hiša je nekoč bila pri Malnih, saj so bili Sirkovi mlinarji. [...] 


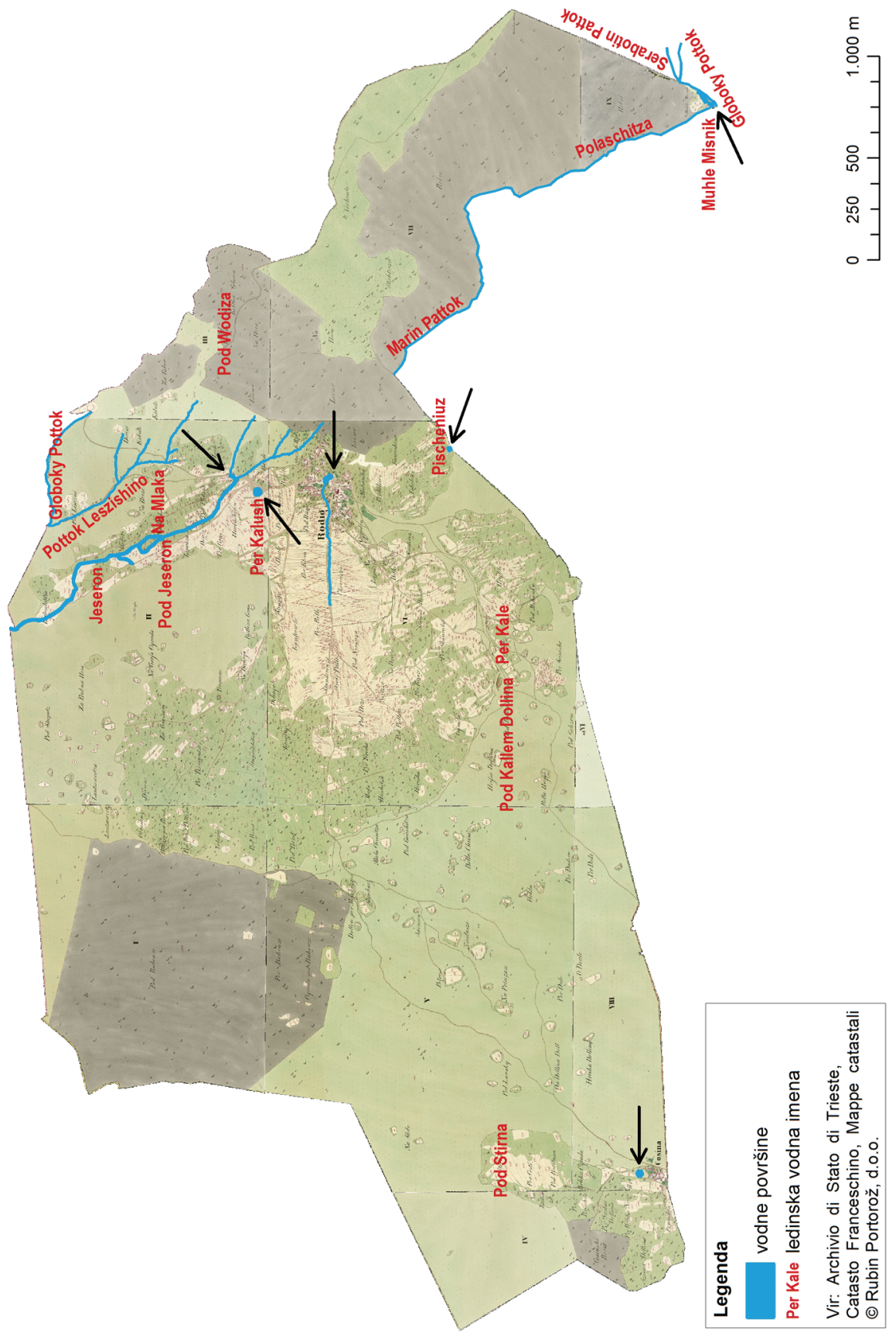

Slika 1 Območje k. o. Rodik z označenimi vodnimi površinami in ledinskimi imeni 


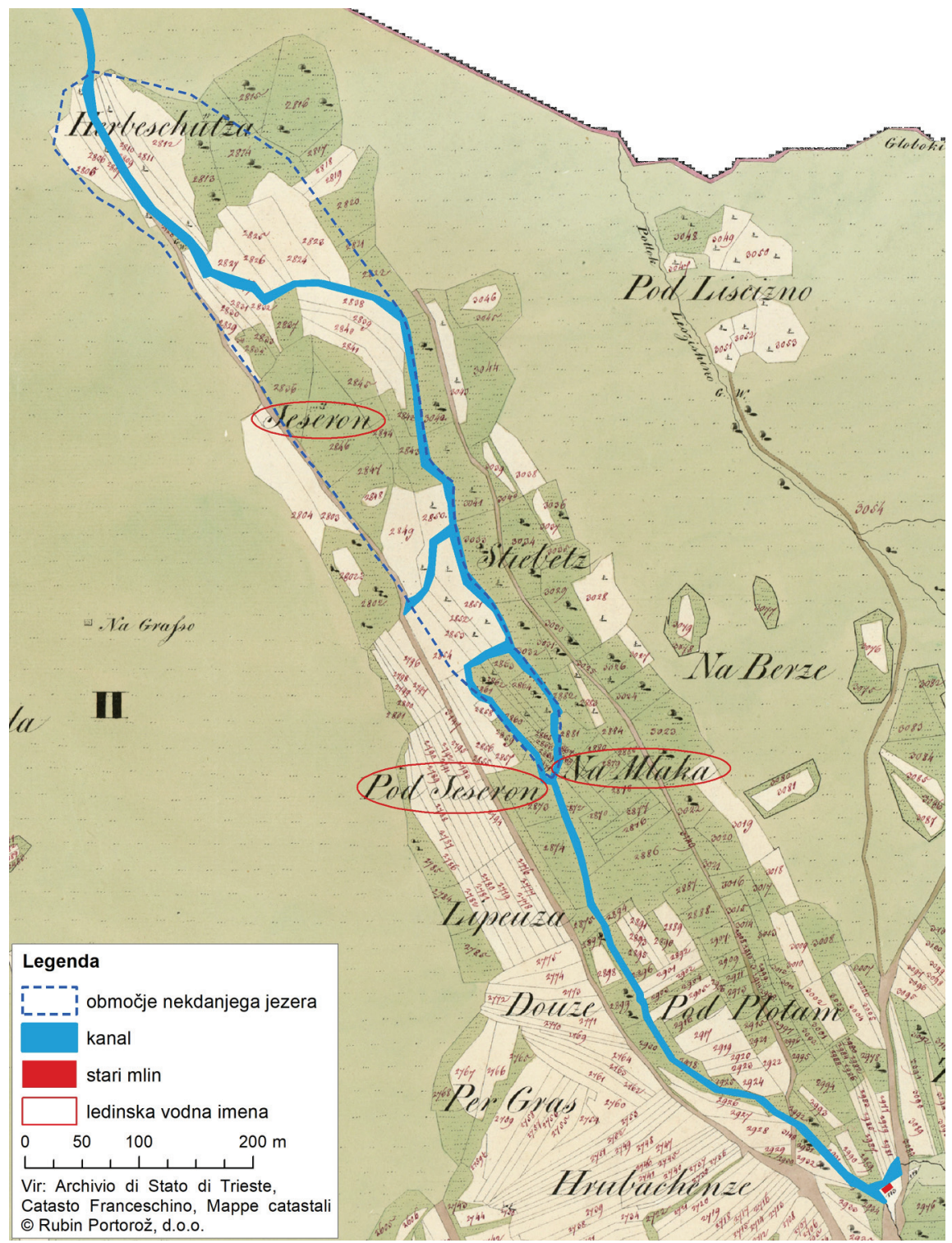

Slika 2 Območje starega mlina z umetnim zajetjem, kanalom in bivšim jezerom

Sirkov mlin, ali po rodiško Malen, je bil v kraju pod Zalogom [...] Sirkovi so naredili jez in mleli, ko je bilo več dežja in je bil Pod koriti močnejši zvirk. Poleti, ob suši, ni bilo vode in niso mleli. Zato so Rodičani skovali zbadljivo pesmico: Sirkov malen melje po malen, če je 
suša, posluša, če je muoča, stuča. Danes je od Sirkovega mlina ostalo le ledinsko ime Pri malnu. [Peršolja 2009, 39-40]

Ljudsko izročilo torej potrjuje obstoj mlina in izgradnjo umetnega zajetja z jezom, vsaj v navedenem pričevanju pa ne pozna več daljšega kanala ter še starejšega jezera. Drugje je zabeležena časovno neopredeljena informacija, vsekakor iz novejšega obdobja, da so prali v »Pravniku ob melinskem vodnem zajetju ali pa v Zalogih «(Peršolja 1997, 139), kar verjetno pomeni isti kraj ob starem mlinu. Na podlagi vsega navedenega je možno postaviti hipotezo, da se je z zajezitvijo (sezonskih, morda hudourniških) voda, ki so ustvarjale (občasno) jezero, ustvarila regulacija, ki je omogočala vsaj sezonsko delovanje mlina in preprečevala poplavljanje zemljišč (kanal namesto bivšega "jezera «), tako da jih je bilo mogoče obdelovati, ne da bi zaradi tega izgubili vodni vir (voda je ostajala v kanalu). Preostali, na karti Franciscejskega tanjše narisani, vodotoki pa so bili verjetno občasnejše narave, to je hudourniške ali pa kraške, saj so vznikali in ponikali.

\section{O navidezni izključno kmečki podobi vasi}

Poročilo iz leta 1830 stanje vasi opisuje v turobnih odtenkih, ki so sicer skupni večini katastrskih opisov naselij in kmečkih domovanj na tem območju, kar kaže na to, da poleg stvarnosti zrcalijo tudi pogled zunanjega urbanega opazovalca. A v našem primeru izstopa izreden dejavnik. »V vasi Rodik se hiše tiščijo vse skupaj, med njimi se nahaja župnijska cerkev [...] Tu ni nobene šole, niti nobenega omembe vrednega predmeta, tudi se ne ve za kak zgodovinski dogodek." Hiše v Rodiku so bile "vse grajene iz kamna, vezanega $z$ malto in krite $z$ rženo slamo. Njihovo stanje je bedno, posebej po nesrečnem požaru, ki so ga utrpele decembra 1816, ko so bile v tej okoliščini v veliki večini uničene. Njihovo sedanje stanje je tesno, nizke in mračne so, grajene brez vsakega reda. Taka so tudi gospodarska poslopja.« Turobnost te slike je torej izrecna posledica uničujočega požara, kar po vsej verjetnosti velja tudi za slamnato kritino. Na Krasu so bila namreč tedaj s slamo krita le redka domovanja, medtem ko je bila slamnata kritina pravilo za gospodarska poslopja. Zato lahko sklepamo, da so v Rodiku po požaru ukrepali tako, da so hiše prekrili s slamo kot obliko čim hitrejše in cenejše obnove ostrešij ter da je tako stanje vztrajalo še desetletje in pol kasneje.

V rodiškem protokolu stavbnih parcel iz leta 1820 je mogoče našteti skupaj 109 različnih stavb, od katerih je 7 sestavljalo zaselek Kozina, ki ga izvzemamo iz nadaljnje analize, tako da sta samemu Rodiku pripadali 102. 
Preglednica 2 Vrste in višina stavb v Rodiku po številu (leto 1820)

\begin{tabular}{lrrrr}
\hline Vrsta poslopja & $(1)$ & $(2)$ & $(3)$ & $(4)$ \\
\hline Stanovanjsko in gospodarsko poslopje & 48 & 12 & 17 & 77 \\
Gospodarsko poslopje & 6 & 0 & 0 & 6 \\
Stanovanjska hiša & 4 & 1 & 0 & 5 \\
Javno poslopje & 2 & 1 & 0 & 3 \\
Podrtija in ruševina & 7 & 0 & 0 & 7 \\
Drugo & 4 & 0 & 0 & 4 \\
\hline Skupaj & 71 & 14 & 17 & 102 \\
\hline
\end{tabular}

Opombe Naslovi stolpcev: (1) pritlično, (2) enonadstropno, (3) enonadstropno stanovanjsko in pritlično gospodarsko, (4) skupaj.

Tu so odločno prevladovale enote, ki so združevale stanovanjsko in gospodarsko poslopje, takih je bilo 77, kar pomeni približno tri četrtine vseh. Vse ostale tipologije in funkcije stavb so bile posledično manj zastopane: tako je bilo popisanih 6 izključno gospodarskih poslopij, 4 stanovanjske hiše in ena nedograjena, 6 podrtij in ena ruševina (nem. Steinhaufen - dobesedno kup kamenja) ter tri javna poslopja, in sicer srenjska hiša (občinski dom), župnišče in cerkev. Popisanih je bilo še nekaj drugih gospodarskih stavb, $\mathrm{h}$ katerim se vrnemo kasneje. V opisu vasi smo prebrali oceno, da so bile hiše v Rodiku "nizke«, a to še ne pomeni, da so bile vse pritlične. Iz popisa stavbnih parcel namreč izhaja, da so pritlična poslopja res prevladovala, bilo pa je tudi kar nekaj enonadstropnih. Povsem pritličnih stavb je bilo okoli $70 \%$ (z vštetimi podrtijami), povsem enonadstropnih pa okoli $14 \%$, vključno s cerkvijo, ki so jo kot tako opredelili v samem v popisu. Znotraj najbolj razširjene tipologije stavb, to je kombinacije stanovanjskega in gospodarskega poslopja, je bil dokaj pogost vzorec, pri katerem je bil stanovanjski del enonadstropen, gospodarski pa pritličen. Zato lahko polovico tovrstnih poslopij dodamo v izračun in ugotovimo, da je bilo dejansko $20 \%$ vseh stavb benonadstropnih (če bi ne upoštevali podrtij, pa bi ta vrednost dosegla skoraj četrtino) - toliko višjih ostrešij je štrlelo iz res pretežno pritličnega rodiškega "skylina«. $Z$ vidika bivanjskih razmer je zanimiv delež obeh tipologij stavb med samimi stanovanjskimi poslopji: teh je bilo 82, izmed katerih je bilo 30 enonadstropnih, kar pomeni dobra tretjina $(36,6 \%$; preglednica 2).

$\mathrm{Z}$ namenom, da si ustvarimo še nekoliko jasnejšo predstavo o bivanjskih razmerah, je na podlagi podatkov o številu in tipologijah stavb (preglednica 2) ter površine stavbnih zemljišč (preglednica 7) mogoče približno izračunati stanovanjsko površino, s katero je okoli leta 1830 razpolagal vsak od 
476 Rodičanov. Ko odštejemo javne stavbe, dvorišča, gospodarska in druga poslopja in ob upoštevanju deleža enonadstropnih stanovanjskih stavb ter dejstva, da so bili hišni zidovi dokaj debeli, pridemo do ocene, da je vsak Rodičan $\mathrm{v}$ povprečju razpolagal $\mathrm{z} 11$ do 14 kvadratnih metrov bivalne površine v stanovanjskih stavbah. ${ }^{4}$

Pri gospodarskih poslopjih so v popisu stavb kot obliko meritve njihove zmogljivosti navedli število glav različne živine, za katere je bil prostor v hlevskem delu. Na tej podlagi je mogoče izračunati, da je bilo v rodiških hlevih prostora za skupaj 158 glav goveda, 458 ovc, 84 prašičev in enega konja, s čimer so ocenjene zmogljivosti presegale popisani stalež živine, kakršnega izkazujejo podatki tako $v$ vprašalniku (1819) kot v poročilu operata. Slednji je povzet po uradni konskripciji iz leta 1827 (prašiči so prešteti kasneje, posebej za namen katastra), med njima pa so opazne razlike (preglednica 3). Bistveno nižje število ovc in goveda v letu 1819 je lahko stvar namernega prikrivanja s strani predstavnikov Rodičanov ali pa dejstva, da so tedaj vaški možje navedli število le za vas Rodik, ne pa tudi za zaselek Kozino, katere podatki so zajeti v vrednostih za leto 1827/1830. Kljub temu je razlika v vrednostih tolikšna, da je kot dodatno razlago mogoče pomisliti na posledice požara, ki je Rodik zajel le poltretje leto pred zapisom vprašalnika in prav gotovo poškodoval hleve, morda povzročil tudi pogin živine in njeno prodajo za pridobivanje sredstev, potrebnih za obnovo stavbnega fonda. Vsekakor podatki nakazujejo izboljšanje staleža živine med letoma 1819 in 1830 (preglednica 3).

Gospodarskih poslopij, uporabnih v hlevske namene, je bilo v Rodiku 66, na Kozini pa le 3, a je bila njihova zmogljivost zelo različna, saj so bili na Kozini nadpovprečno prostorni, tu je tudi najti največjega, ki je zmogel 14

\footnotetext{
${ }^{4}$ Stavbnih površin je bilo po Franciscejskem katastru skupaj za $62 \mathrm{~m}^{2}$ na prebivalca. Ocenimo, da so dvorišča (pri cerkvi pokopališče) obsegali polovico stavbnih površin, in nam tako ostane $31 \mathrm{~m}^{2}$ na prebivalca. Od te površine odštejemo $7 \%$ iz naslova podrtij in ruševin (7 primerov od skupaj 102 stavb), $4 \%$ za 3 javna poslopja (cerkev obračunamo $z$ dvojno površino, ker je večja od povprečne stavbe) ter dodatne $4 \%$ za 4 druga poslopja, tako da skupaj odvzamemo $15 \%$ stavbnih površin, ostane $26,35 \mathrm{~m}^{2}$ na prebivalca. To vrednost razpolovimo na podlagi ocene, da je na gospodarska poslopja odpadla polovica površine, nakar nam preostane $13,175 \mathrm{~m}^{2}$ bivanjske površine na prebivalca. Tej vrednosti dodamo $36,6 \%$ površine na podlagi odstotka enonadstropnih stavb, s čimer dobimo $18 \mathrm{~m}^{2}$ bivanjske površine na prebivalca, ki pa je bruto vrednost v smislu, da vsebuje tudi zidove stanovanjskih stavb. Ker so bili ti dokaj debeli, je mogoče oceniti, da so zasedali med 20 do $40 \%$ bruto površine, odvisno od velikosti stavbe (manjša je stavba, večji delež površine odpade na zidove). Po tej poti je mogoče oceniti, da je vsakemu Rodičanu pripadlo med 10,8 in $14,4 \mathrm{~m}^{2}$ neto bivanjske površine $\mathrm{v}$ stanovanjski stavbi.
} 
Preglednica 3 Stalež živine in zmogljivost hlevskih prostorov (1819/1830)

\begin{tabular}{|c|c|c|c|c|c|}
\hline \multirow[t]{2}{*}{ Vrsta živine } & \multirow{2}{*}{$\begin{array}{r}\text { Stalež Rodik } \\
\text { (brez Kozi- } \\
\text { ne?) } 1819\end{array}$} & \multirow{2}{*}{$\begin{array}{r}\text { Stalež Rodik } \\
\text { in Kozina } \\
1827 / 1830\end{array}$} & \multicolumn{3}{|c|}{ Zmogljivost hlevov 1820} \\
\hline & & & $\begin{array}{r}\text { Rodik } \\
(66 \text { hlevov) }\end{array}$ & $\begin{array}{r}\text { Kozina } \\
\text { (3 hlevi) }\end{array}$ & Skupaj \\
\hline Konji & 2 & 3 & 1 & $\mathrm{o}$ & 1 \\
\hline Voli & 8 & 2 & 158 & 14 & 172 \\
\hline Krave & 84 & 157 & & & \\
\hline Ovce & 200 & 410 & 458 & 170 & 628 \\
\hline Prašiči & 35 & 30 & 84 & o & 84 \\
\hline
\end{tabular}

glav goveda in 100 ovc; pripadal je Blažu Gropajcu, daleč največjemu živinorejcu v katastrski občni Rodik. $V$ večini hlevov v vasi Rodik pa je bilo prostora za do dve kravi (44), veliko je bilo tudi takih, v katerih so lahko domovale do štiri ovce (40), in takih, kjer je svoj prostor mogel najti največ en prašič (45). Po drugi strani so le trije hlevi zmogli pet ali več glav goveda, za trideset ali več ovc jih je bilo 5 , za več kot dva prašiča pa le 5 . Te vrednosti nam povedo, da je bila večina hlevov majhnih in nam na svoj način nakazujejo, da je bila razslojenost na vasi precejšnja, čeprav so navedeni podatki merilo velikosti prostorov, ne pa neposredno tudi socialnih razlik, saj je v nekaterih primerih posamezen gospodar lahko posedoval po več poslopij, $\mathrm{v}$ drugih pa je bilo pod isto hišno številko povezanih več gospodarjev in vsak od njih je razpolagal s svojimi prostorskimi zmogljivostmi. Poleg tega velikost hleva še ne pomeni, da je bil tudi zapolnjen z živino. Vsekakor je največji hlev v Rodiku pripadal Andreju Prelcu, v njem je bilo prostora za 5 glav goveda in 50 ovc, Martin Čebohin pa je imel največ prostora za govedo, in sicer za 8 glav, a skoraj polovica vseh hlevov na vasi je zmogla do 2 kravi, 5 ovc in 2 prašiča (preglednici 4 in 5 ).

Prevladujoča usmerjenost katastra $\mathrm{v}$ kmetijsko dimenzijo prostora, zemlje in naselij se neizogibno zrcali v informacijah, ki jih nudi, vključno z opredelitvijo dejavnosti in stanu prebivalstva kot izključno kmečkega. Kljub temu se s pozornejšim naborom raztresenih omemb slika razširi in obogati do mere, ko se vaška stvarnost vendarle izkaže za kompleksnejšo. Tako ob trditvi, da se v katastrski občini Rodik »ne izvaja nobena gospodarska dejavnost [industria] razen obdelovanja zemlje«, poročilo cenilnega operata že v naslednjem stavku pove, da je tu mogoče našteti ne ravno zanemarljivo število "14, ki imajo patent, in to so mali trgovci, gostilničarji, mesarji, krojači, čevljarji in drugi, ki izvajajo nek poklic « ter so kot taki priglašeni (imajo patent). 


\section{Preglednica 4}

Prostornost hlevov v Rodiku po velikostnih skupinah (1820)

\begin{tabular}{lr}
\hline Zmogljivost hleva & Število hlevov \\
\hline $1-2$ kravi, o-1 prašič & 12 \\
1-2 kravi, 1-4 ovce, o-1 prašič & 11 \\
2 kravi, 3-5 ovc, 1-2 prašiča & 10 \\
2 kravi, 8-15 ovc, 1-3 prašiči & 7 \\
3 krave, o-6 ovc, o-2 prašiča & 7 \\
3 krave, 10-30 ovc, o-2 prašiča & 4 \\
4 krave, 5-10 ovc, 1-2 prašiča & 4 \\
$4-5$ krav, 15-35 ovc, 2-4 prašiči & 4 \\
5 krav, 50 ovc, 6 prašičev & 1 \\
8 krav, 8 ovc, 2 prašiča & 1 \\
Drugo & 5 \\
\hline Skupaj hlevov & 66 \\
\hline
\end{tabular}

Preglednica 5 Lastniki štirih največjih in najmanjših hlevov v Rodiku (1820)

\begin{tabular}{|c|c|c|c|c|c|c|}
\hline \multirow[t]{2}{*}{ Št. } & \multirow[t]{2}{*}{ Gospodar } & \multirow{2}{*}{$\begin{array}{l}\text { Katastrska/ } \\
\text { hišna št. }\end{array}$} & \multicolumn{4}{|c|}{ Zmogljivost hleva, izražena s številom živine } \\
\hline & & & Govedo & Ovce & Prašiči & Skupaj \\
\hline 1. & Andrej Prelec & $84 / 63$ & 5 & 50 & 6 & 61 \\
\hline 2. & Jožef Cerkvenik & $98 / 9$ & 4 & 40 & 4 & 48 \\
\hline 3. & Martin Bernejčič & $68 / 76$ & 5 & 35 & 4 & 44 \\
\hline 4. & Jožef Race & $61 / 24$ & 4 & 30 & 3 & 37 \\
\hline 63. & Štefan Babič & $38 / 49$ & 1 & o & $\mathrm{o}$ & 1 \\
\hline 63. & Anton Komar & $51 / 50$ & 1 & o & $\mathrm{o}$ & 1 \\
\hline 65. & Ivan Žiberna & $56 / 55$ & $\mathrm{o}$ & $\mathrm{o}$ & 1 & 1 \\
\hline 65. & Štefan Jerman & $54 / 53$ & 0 & $\mathrm{o}$ & 1 & 1 \\
\hline
\end{tabular}

Poleg tega je v seznamu stavbnih parcel zaslediti nekoga, ki je opredeljen kot »kmet in mizar« (Martin Čebohin). Prav tam izvemo tudi, da je gostilničar (Ivan Samsa) živel in deloval na Kozini in ne v samem Rodiku, kjer se gostilna ne omenja, zato pa so navedene druge stavbe, namenjene nekmetijskim gospodarskim dejavnostim. Taka je v sami vasi kovačija, ki jo je posedoval Valentin Sluga, zunaj središča vasi se je nahajal že omenjeni Dujčev mlin, ki je pripadal Andreju Dujcu, čeprav sta oba (Sluga in Dujc) opredeljena le kot »kmeta « in ne kot kmet in kovač oziroma kmet in mlinar. Nekoliko oddaljeni od vasi sta navedeni še dve stavbi, namenjeni proizvodnji, ki sta obenem zanimivi zaradi tega, ker ju ne bi nujno pričakovali: to sta bili opekarna (nem. Ziegel Brennofen, dobesedno "peč za opeke«) in zraven nje "skladišče opek« (nem. Ziegel Schupfen), ki sta bili po tlorisu sodeč si- 


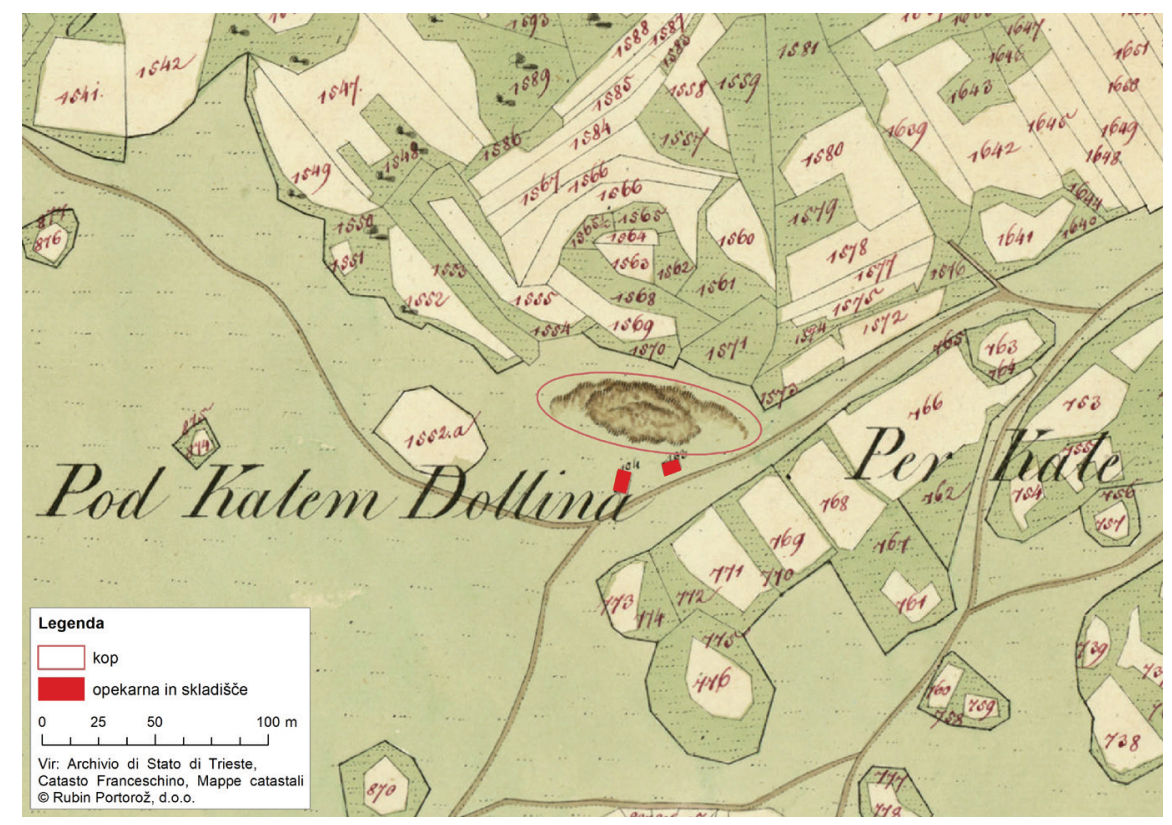

Slika 3 Opekarna s skladiščem in kopom v bivšem kalu

cer manjši stavbi. Tako mlin kot območje opekarne smo v resnici že srečali, ko smo obravnavali vodne vire. Dujčev mlin je isti, ki smo ga že srečali pod imenom »mlin Misnik«. V neposredni bližini opekarne in skladišča opek pa je na katastrski karti jasno razpoznaven tudi kop, kjer so očitno črpali potrebno surovino za to dejavnost. Opekarna in kop sta se nahajala na obočju pod vasjo $z$ ledinskim imenom »Per Kale«, kjer pa voda ni vrisana. Povsem razumno je sklepati, da so kot surovino za izdelavo opek uporabljali dno bivšega, presahlega kala, tako da se je kop nahajal na mestu bivšega kala (slika 3).

Kot lastnik opekarne je naveden Jožef Race, kot solastniki skladišča pa Jožef Komar, Martin Babuder in Anton Bernečič. Sklepamo lahko, da so delovali kot nekakšni družabniki. Nekaj dodatnih drobcev na to temo je najti v seznamu posestnikov kmetijskih zemljišč. Kot "gostilničar na Kozini« je v tem dokumentu naveden Edger Samson, v Rodiku pa so s specifičnim poklicem omenjeni še Lovrenc Felicijan, »kmet in tkalec«, Štefan Čebohin, "mali trgovec s tobakom" (Toback Verschleisser), Andrej Čebohin, »kmet in kovač«, Martin Čebohin, »kmet in mizar« ter že omenjeni Andrej Dujc, »mlinar«.

Če vse navedene drobce združimo v preglednico, ugotovimo, da je bilo v 
Preglednica 6 Seznam neagrarnih dejavnosti v Rodiku (s Kozino)

\begin{tabular}{|c|c|c|c|}
\hline Št. & Poročilo* & Seznam lastnikov stavbnih parcel & Seznam lastnikov zemljiških parcel \\
\hline 1. & Mali trgovci & & Mali trg. s tobakom Štefan Čebohin \\
\hline 2. & Gostilničarji & Gostilničar na Kozini Ivan Somsa & Gostilničar na Kozini Edger Samson \\
\hline 3. & Mesarji & & \\
\hline 4. & Krojači & & \\
\hline 5 . & Čevljarji idr. & & \\
\hline 6. & & Kmet in mizar Martin Čebohin & Kmet in mizar Martin Čebohin \\
\hline 7. & & Kovačija, Valentin Sluga & \\
\hline 8. & & & Kmet in kovač Andrej Čebohin \\
\hline 9. & & Mlin, Andrej Dujc & Mlinar Andrej Dujc \\
\hline 10. & & Opekarna, Jožef Race & \\
\hline 11. & & Skladišče opek, Jožef Komar & \\
\hline 12. & & Skladišče opek, Martin Babuder & \\
\hline 13. & & Skladišče opek, Anton Bernečič & \\
\hline 14. & Skupaj 14 & & Kmet in tkalec Lovrenc Felicijan \\
\hline
\end{tabular}

Opombe ${ }^{*}$ Operata, poklici s patentom.

k. o. Rodik dejansko vsaj 14 posameznikov, ki so se ukvarjali z neagrarno dejavnostjo, pri čemer je mogoče našteti vsaj deset različnih poklicev (gostilničar, mali trgovec, mizar, kovač, mlinar, tkalec, proizvajalec in prodajalec opek ter mesar, krojač in čevljar), s tem da za nekatere od navedenih nimamo omenjenega nosilca dejavnosti, da seznam ni nujno popoln in da vsi niso bili nujno uradno priglašeni s svojo dejavnostjo poleg kmetijske (preglednica 6). $Z$ vidika virov denarnega dohodka je smotrno spomniti še na razširjeno prakso, ki jo navaja poročilo operata, to je prodajo presežka določenih kmetijskih pridelkov v okolici Rodika in v mestu Trst, in sicer zlasti zelja, krompirja in repe.

Kakor pred tem v primeru koruze in še bolj krompirja lahko o prodoru modernih dobrin $\mathrm{v}$ vsakdanje življenje rodiške skupnosti govorimo tudi za tobak, ki ga je preprodajal vaščan Štefan Čebohin, in sicer prav gotovo ne le na vasi, temveč tudi v njeni okolici. Tudi v primeru tobaka ne gre za neko absolutno noviteto, ki bi bila časovno avantgardna, saj se je $\mathrm{v}$ tem prostoru njegova poraba širila že v 18 . stoletju, vseeno pa predstavlja zanimiv dokaz o razširjenosti vedenjskega in potrošnega vzorca na primorskem podeželju $\mathrm{v}$ povezavi z modernim blagom, ki ni povezan z zadovoljevanjem preživetvenih potreb.

Kolikšna pa je bila razširjenost neagrarnih dejavnosti v skupnosti? Poročilo operata kot skupno število družin v k. o. Rodik na podlagi konskripcije 
iz leta 1827 navaja število 82, ki odgovarja številu hišnih številk v dokumentaciji katastra (prav tako 82). Če pa to primerjamo s poimenskim seznamom lastnikov stavbnih parcel, ugotovimo, da je bilo navedenih vsaj 8 gospodarjev več (kar bi skupaj naneslo go družin), saj se pod isto hišno številko, in sicer v isti ali v drugih stavbah, navajata tudi po dve imeni. Ti "presežni " gospodarji v seznamu lastnikov zemljiških parcel izkazujejo tudi posest nad kmetijskimi zemljišči, kar bi lahko potrjevalo sklepanje, da gre za dejanske dodatne družinske poglavarje. Po drugi strani pa bi ti dodatni gospodarji vendarle utegnili biti povezani v širše, razčlenjene družine, kar bi bilo podlaga za to, da so jim prisodili isto hišno številko, čeprav so se njihove hiše nahajale na drugem koncu vasi ali celo na Kozini. Verjetno lahko to neskladje razumemo kot sliko procesa členitve družin in vzpostavljanja novih. Vsekakor je na Kozini mogoče našteti 5 gospodinjstev v seznamu lastnikov stavb in $6 \mathrm{v}$ seznamu lastnikov zemljišč. To pomeni, da je bilo $\mathrm{v}$ sami vasi Rodik 77 družin (če upoštevamo tudi dodatne gospodarje, pa 84; katastrsko poročilo sicer navaja še drugačno število, in sicer 85 gospodarjev). Če kot število izvajalcev neagrarnih dejavnosti upoštevamo (vsaj) 14 posameznikov in kot število družin vzamemo 82 ter presodimo, da je bil v vsaki družini dejaven po en član, ugotovimo, da so se v petini (vsaj 17\%) družin ukvarjali tudi z drugimi dejavnostmi poleg kmetijske. ${ }^{5}$ Prebivalcev, ki so se ukvarjali (tudi) z neagrarnimi dejavnostmi, pa je bilo po vsej verjetnosti bilo več, kar izkazuje kataster. K taki presoji napeljuje že samo dejstvo, da med izvajalci nekmetijskih dejavnosti ni navedena nobena ženska, za kar lahko podvomimo, da bi predstavljalo resnično sliko. Viri za starejše obdobje nakazujejo precejšnjo razširjenost obrtniških poklicev in nasploh neagrarnih dejavnosti med Rodičani (Peršolja 2009). Predlagana je bila npr. domneva, da je že pred sredino 17. stoletja "v Rodiku delovala stavbarska delavnica«, v okolici vasi pa se je nahajal tudi »kamnolom«, izpričan najkasneje leta $1675 .{ }^{6}$ Ker pa zgodovina ne poteka nujno enosmerno v smeri rasti in razvoja, pričevanj za starejša obdobja ne moremo jemati kot dokaz za začetek 19. stoletja, temveč kvečjemu le kot indic.

Uvodoma ugotovljeno intenzivno obdelovanje kmetijskih zemljišč in poseganje na trg s prodajo pridelkov ter pravkar omenjena prisotnost neagrarnih dejavnosti sta tvorila pomembna dejavnika vzdržnosti večsto-

${ }^{5}$ Do enakega deleža pridemo tudi za sam Rodik ob upoštevanju 13 izvajalcev neagrarnih dejavnosti (brez kozinskega gostilničarja) in 77 družin.

${ }^{6}$ Premrl (2004, 287, 295-296), ki je kamnolom lokaliziral v odkopih v dolini »v Bodenjivcu na območju Male griže pri Rodiku«. 
Preglednica 7 Obseg različnih vrst površine po namembnosti v k. o. Rodik (1830)

\begin{tabular}{lrrrrr}
\hline Vrsta površine & $(1)$ & $(2)$ & $(3)$ & $(4)$ & $(5)$ \\
\hline Navadna orna zemljišča & 245 & 346 & 141,11209 & 11,686 & 0,296 \\
Navadni travniki & 273 & 538 & 157,29399 & 13,026 & 0,330 \\
Navadni pašniki & 891 & 570 & 512,93977 & 42,478 & 1,078 \\
Pašniki z lesom & 53 & 1.021 & 30,86643 & 2,556 & 0,065 \\
Bukovi gozdovi & 47 & 977 & 27,39785 & 2,269 & 0,058 \\
Mešani gozdovi & 559 & 69 & 321,70694 & 26,642 & 0,676 \\
Vrtovi s sadjem & 8 & 910 & 4,93082 & 0,408 & 0,010 \\
\hline Skupaj obdelovalna zemljišča & 2.078 & 1.231 & $1.196,24842$ & 99,066 & 2,513 \\
Stavbna zemljišča & 5 & 190 & 2,94560 & 0,244 & 0,006 \\
Neplodna tla, vodne in cestne površine & 14 & 779 & 8,33649 & 0,690 & 0,017 \\
Skupna površina k. občine & 2.098 & 600 & $1.207,53078$ & 100,000 & 2,536 \\
\hline
\end{tabular}

Opombe Naslovi stolpcev: (1) oralov, (2) sežnjev, (3) skupaj hektarjev, (4) delež v odstotkih, (5) hektarjev na prebivalca (476 preb.). 1 oral $=0,57546$ ha; 1 seženj (Klafter) $=3,595 \mathrm{~m}^{2}$.

letnega procesa drobljenja kmečkih gospodarskih enot in posameznih zemljišč. Slednji je do leta 1830 privedel do stanja, ko po besedah katastrskega poročila v Rodiku »eno večjih posesti sestavljajo 2-3 orala njiv in 7-8 oralov travnikov« - to pomeni 1,15 do 1,73 hektarov njivskih in 4 do 4,6 hektarov travnatih površin, kar seveda predstavlja kar majhen obseg za največje kmetije na vasi (skupaj 5-6 ha). V konskripciji iz leta $1827 \mathrm{so} \mathrm{v}$ k. o. Rodik skupno našteli 476 prebivalcev (240 moškega in 236 ženskega spola), kar pri 82 družinah nanese povprečje 5,8 družinskih članov. ${ }^{7}$ Vsak prebivalec Rodika je tedaj v povprečju lahko računal na le okoli 0,3 ha njiv in prav toliko travnikov, na približno 1 ha pašnika in $100 \mathrm{~m}^{2}$ vrta (preglednica 7).

Na temo prebivalcev je mogoče kako besedo nameniti tudi vprašanju njihove pismenosti. V sklopu poročila operata se nahajata dva "protokola i iz leta 1826, na katerih so podpisani vaški možje, ki so sodelovali pri zbiranju podatkov za namene katastra, med njimi je bil tudi rodiški župan. Samo eden od njih je znal pisati in ta je zapisal vsa imena, nakar se je vsak zraven svojega podpisal s križem:

\section{$X$ Anton Benetiz Shopan \\ $X$ Martin Zhebohin $X$ Anton Shuman}

\footnotetext{
${ }^{7} \mathrm{Na}$ tej podlagi lahko število prebivalcev Kozine ocenimo na 29 in posledično samega Rodika na 447 .
} 


\author{
X Josef Raze \\ $X$ Andrey Raze \\ $X$ Anton Bernetiz \\ $X$ Jerni Babig \\ Skosi mene \\ Mihal Shuman \\ Tako proshen
}

Ali je bil zunaj kroga teh bolje obveščenih osmih mož (poleg župnika) tedaj pismen še kdo drug, nam kataster ne pove.

Rodiška skupnost pa ni premogla le svojega župana, temveč je bila lastnica nezanemarljivega deleža nepremičnin na vasi, tudi če odmislimo srenjsko zemljo. V Franciscejskem katastru je namreč kot lastnina skupnosti navedenih skupaj sedem stavbnih parcel oziroma objektov, in sicer občinska hiša, cerkev s pokopališčem, župnišče, dvorišče, dve podrtiji in ena ruševina ter še eno poslopje, oddano v najem. $S$ tem je bila skupnost ena večjih lastnic nepremičnin, o razlogu za razmeroma veliko število poškodovanih stavb v njeni lasti pa na tem mestu ne bomo ugibali. V vsakem primeru se $v$ Rodiku potrjuje znani vzorec, po katerem so vaške skupnosti upravljale s posestjo lokalne cerkve, in sicer pogosto preko posebne institucije, bratovščine. ${ }^{8}$ Tudi v Rodiku je delovala bratovščina. Iz informacij, raztresenih v Peršoljini knjigi o rodiških rodovih in povzetih po računskih knjigah rodiške bratovščine svetega Valentina iz 17. stoletja, je mogoče razbrati, da je bratovščina tudi tu imela svoje ključarje, ki so bili izvoljeni izmed njenih članov (ti so plačevali članarino) in so vodili njene račune (prihodke in izdatke) ter upravljali s cerkveno posestjo. Med dejavnostmi rodiške bratovščine zasledimo stavbe, oddane v najem, zemljišča, oddana v kmetovanje, živino, oddano v rejo, dajanje posojil in podobno (Peršolja 20o9, 21, 45-46, 385-386; Peršolja in Pregelj 1997, 95).

\title{
Med vidnim, navideznim in zastrtim
}

Izvorna namembnost Franciscejskega katastra močno opredeljuje tipologijo podatkov in informacij, ki jih vsebujeta tako njegov spisovni kot kartografski del. Posledično odločno prevladuje poudarek na vsebinah in značilnostih, povezanih s kmetijstvom. Kljub temu je na podlagi uradnih usmeritev in zavzetosti sestavljavcev v nekaterih njegovih delih mogoče zaslediti tudi informacije, ki presegajo ožjo sfero kmetijskih vidikov, čeprav so

\footnotetext{
${ }^{8}$ Panjek (2018b) ter tam navedena literatura.
} 
vselej v podrejeni vlogi in dokaj daleč od sistematičnosti, natančnosti in zanesljivosti, ki kataster odlikujejo na področju kmetijstva. To nas sicer ne preseneča, saj zgodovinar vselej dela na osnovi dokumentov, ki so nastali v namene, drugačne od zgodovinskega raziskovanja, in mora to upoštevati.

Podobno velja za različne subjekte, ki so bili vključeni v njegov nastanek. Predstavnikom lokalne skupnosti ni bilo v interesu, da bi poudarjali pozitivne vidike svojega gospodarstva, saj je bila končni rezultat katastra vendarle obdavčitev. Zato $\mathrm{v}$ njihovih opisih in mnenjih prevladuje poudarek na šibkostih in pomanjkanju gospodarskih in naravnih virov. Na drugi strani so stali uradniki, ki so zaradi samih značilnosti vsakega katastra na eni strani težili k poenostavljanju lokalne stvarnosti, da bi jo lahko ukalupili v standardizirane obrazce in vnaprej predvidene kategorije. Obenem so bili večkrat nosilci kmečkemu svetu zunanjega pogleda, kar pa ni privedlo do pozitivnih učinkov v smislu večje »objektivnosti«, temveč je zlahka povzročilo, da so prezrli lokalna znanja, prakse, značilnosti in vrednote (Scott 1998, 12-15; Panjek 2015a, 80). V tem prispevku je morda najjasnejši tovrsten primer ocena zapisovalcev poročila cenilnega operata iz leta 1830, po kateri naj bi v Rodiku ne bilo "nobenega omembe vrednega predmeta, tudi se ne ve za kak zgodovinski dogodek«, ko pa so se na vrhu hriba nahajale ostaline prazgodovinskega naselja, ki so bile prvih znanstvenih obravnav deležne le par desetletij zatem in so bile močno vpete $\mathrm{v}$ samopodobo skupnosti (Slapšak 1997, 22, 28; 2003, 247; Hrobat Virloget 2005).

Če se izognemo ponavljanju vsebinskih ugotovitev o Rodiku, ki so dovolj jasno izpostavljene, in preidemo k specifičnejšim metodološkim sklepom, velja izhajati iz samoumevnega, to je, kako ima vsak del Franciscejskega katastra svoj poudarek. Vsak protokol, seznam in obrazec ter karta prinašajo drugo vrsto podatkov in podob. Obenem se v vsakem najdejo tudi naključnejši oziroma bolj nesistematični podatki in informacije, ki so nam lahko še kako koristni. Opazili smo tudi, da se le-ti med seboj ne samo dopolnjujejo, ampak so si mestoma protislovni, in sicer zaradi same namembnosti vira in specifik njegovih sestavnih delov kakor tudi zaradi nosilcev različnih interesov in pogledov, ki so sodelovali pri njegovem nastajanju. Menim, da prispevek nazorno izkazuje bogastvo podatkov in informacij, ki jih nudi Franciscejski kataster, še posebej pa dokazuje, kako lahko v primeru študije na mikronivoju in $\mathrm{z}$ doslednim kritičnim pristopom izluščimo in razumemo bistveno več, če jih med seboj povežemo in dopolnjujemo na načine, ki jih sam vir ni predvidel. Kadar se ne osredotočimo le na enega ali dva protokola in kombiniramo več vrst spisovnih in kartografskih dokumentov, bistveno povečamo povednost vira. Na ta način se pokažejo na prvi 
pogled zakrite značilnosti lokalne stvarnosti ter dosežemo globlji in celovitejši vpogled vanjo - takega, ki seže onkraj vidne in navidezne katastrske upodobitve. $V$ tem smislu se razkrivajo tudi meje med vidnim, navideznim in zastrtim v Franciscejskem katastru.

\section{$\mathbf{O}$ delitvah vasi z zgodovinskega vidika}

V nadaljevanju bomo preverili ali je v posestni strukturi zemljišč in razporejenosti bivališč med rodiškimi gospodinjstvi in gospodarji mogoče zaslediti vzorce, ki bi lahko predstavljali materialno sled vaškega ljudskega izročila o nastanku naselja in o notranjih delitvah skupnosti, kakršne izpričujeta etnološka in folklorna literatura. Posebej bomo poskusili preveriti, ali je izsledke etnoloških raziskav mogoče potrditi z rezultati zgodovinske metode, ali so eni in drugi skladni ter, nenazadnje, kaj lahko zgodovinska obravnava prispeva $\mathrm{k}$ poznavanju skupnosti in razumevanju njenega izročila. V mislih imam zlasti dva vidika lokalne tradicije. Prvi je bolj mitskega značaja in govori o izvoru vasi, ki naj bi nastala iz dveh ločenih komponent, to je iz »Rodičanov« kot (staro)slovenskih naseljencev ter iz »Ajdov« kot staroselcev Rundiktov z vrha rodiške Ajdovščine in obenem priseljencev v novoustanovljenem dolinskem naselju. Drugi vidik je bistveno jasneje in zanesljiveje izpričan $\mathrm{v}$ donedavnih vaških običajih, ki izkazujejo delitev vasi in njenih prebivalcev na dva nasprotujoča si »tabora«, ki sta se ločeno udejstvovala verskih in posvetnih obredij (Hrobat Virloget 2005; 2010a; 2010b). Razumeti je, da omenjeni delitvi sovpadata, saj naj bi zajemali ista dela vasi, ki ju ločujeta glavna vaška ulica in vzporedni potok. Rodik se poleg te osnovne dvodelnosti deli na pet sestavnih delov, ki jim bomo rekli vaške četrti, na kar se bomo v nadaljevanju oprli pri preverjanju materialnih sledi omenjenega ljudskega izročila.

Že na prvi pogled je iz navedenih notranjih členitev jasno, da imamo opraviti z razčlenjenim vaškim mikrokozmosom, kar pa nas ne bi smelo presenetiti ali avtomatično navesti $\mathrm{k}$ misli, da je (bil) v tem pogledu Rodik izjemen primer. Predstave o enolični in enostavni kmečki družbi, v kateri malodane ni bilo prostora in časa za kaj drugega kot za garaško udinjanje golemu preživetju iz rok $\mathrm{v}$ usta in ki je nespremenjena ter pasivna pregazila večstoletna zgodovinska obdobja, so lahko le slika, posneta $\mathrm{z}$ visokoleteče ptičje perspektive kulturno ali kronološko oddaljenih opazovalcev brez pravega občutka za vsakdanje življenje in s pomanjkanjem pozornosti za vse, kar ne prenese nalepke velike in zato pomembne zgodovine. Nizka ločljivost take slike še vedno močno vpliva na prevladujoče videnje zgodovine slovenskega podeželja, da ne rečem "naroda«. Če pa se spustimo na 
bolj »mikro« raven in podeželsko stvarnost pogledamo pobliže, nam večje število slikovnih točk kmalu odstre pogled na izrazito kompleksno kmečko družbo in kulturo, ki je notranje povezana in obenem razčlenjena, sestavljena iz posameznikov, gospodinjstev, družin, rodbin, sorodstev, skupin, slojev, srenjskih institucij, pozicij moči in vsakokratnih interesov ter odnosov s sosednjimi skupnostmi, povezanih $\mathrm{v}$ zapleten preplet solidarnosti in zavezništev ter sporov in zamer. Kmečke skupnosti tudi niso odgovarjale dokaj razširjeni, idealizirani podobi brezpogojne medsosedske solidarnosti, saj je bila kmečka družba tudi izrazito konfliktna, tako do sosednjih skupnosti kot znotraj posamezne skupnosti, v kateri je lahko bila solidarnost selektivna v smislu, da je zajela le nekatere njene sestavne dele. Obenem so kmetje razvili kompleksen gospodarski sistem, ki je segal bistveno onkraj kmetijstva, imeli so svoja lastna pravna pojmovanja, ki so se lahko razlikovala od uradnih razlag, in so v ta namen premogli specifična obredna orodja, s katerimi so jih udejanjali. ${ }^{9}$ Razume se, da so imeli svoje vrednote, da ne omenimo vzporednih verovanj in praks, ki jih v zadnjih letih spoznavamo pod skupnim nazivom "staroverstvo «. ${ }^{10}$ Vse, kar smo navedli, pa je bilo tudi spremenljivo: odmisliti velja nujno prevlado monotone dolgotrajnosti stanja, razmer, značilnosti in pogojev v odsotnosti novosti, dogajanja in sprememb od srednjega veka pa vse do nastopa modernizacije.

V slovenski arheologiji in zgodovinopisju premoremo metodo, ki jo je razvil Andrej Pleterski, na podlagi katere je na primeru gorenjskih vasi prišel do opredelitve izvornih kmetijskih obratov, nastalih ob naselitvi Slovanov oziroma Protoslovencev. Imenujemo jo "retrogradna analiza«, saj izhaja iz informacij in podatkov zemljiških katastrov s konca novega veka in z zahtevnim, dolgotrajnim in kompleksnim postopkom, pri katerem se med drugim opira na urbarje in ledinska imena, za nazaj povezuje in združuje posamezne dele kmetij ter njihove parcele v podobo, ki bi naj odgovarjala prvotnemu stanju gospodarskih zemljiških enot (Pleterski 1989; 2011). $V$ začetni fazi sem se nagibal k temu, da bi to metodo uporabil pri razvozlavanju vprašanja, ali ljudsko izročilo o dveh ločenih izvornih komponentah vasi Rodik odgovarja procesu nastanka in oblikovanja vasi. A pojavila sta se dva metodološka pomisleka. Prvi je skromno število urbarjev za gospostvo Švarcenek, ki mu je pripadal Rodik, ki bi nam lahko bili v oporo, saj niti avtorju najbolj poglobljene raziskave o njem ni uspelo identificirati nobenega pravega urbarja po tistem (znanem) iz leta 1574, ne v slovenskih, italijan-

\footnotetext{
${ }^{9}$ Panjek (2016), s tam navedeno literaturo (posebej S. Vilfan).

${ }^{10}$ O vrednotah glej npr. Bianco (2011) in Panjek (2015a). O staroverstvu glej Medvešček (2015).
} 
skih in niti avstrijskih arhivih (Cova 2009). Kako torej zapolniti dveinpolstoletno časovno vrzel do Franciscejskega katastra? Drugi problem izhaja iz izrazite značilnosti primorskega podeželja, kjer so se vsaj od 16. stoletja dalje hube delile na manjše enote, obenem pa so kmetje razmeroma intenzivno kupovali, prodajali in drugače prenašali posest (dedovanja, dote) nad posameznimi zemljiškimi parcelami. Živahno in zapleteno prehajanje in drobljenje posesti ob prepletanju družin ter pojavljanju novih je lepo razvidno tudi iz rekonstrukcije razvoja posameznih rodiških rodbin (Peršolja 2009).

Tako je mogoče ugotoviti, da je na posameznih hubah $\mathrm{v}$ resnici sedelo več gospodarjev, ne glede na to, kaj je bilo zapisano v urbarjih. V našem primeru so cenilni komisarji v gospostvu Švarcenek že leta 1620 opazili, da nihče izmed gospodarjev hub, poimensko navedenih $v$ prejšnjem originalnem urbarju (1574), ni bil več pri življenju, da so odtlej "nekatere hube tri- ali štirikrat prešle $\mathrm{v}$ druge roke in da jih je bila večina tudi razdeljena na več delov« (Panjek 2002, 51; Cova 2009, 117). Delitve in drobitve so bile uradne, torej take, ki jih je gospostvo zaznalo in zabeležilo, a tudi prikrite, saj so se na ta način kmetje izogibali plačevanju gospoščinskih pristojbin za prenos posesti. To je privedlo do stanja, v katerem so hube, zabeležene $\mathrm{v}$ urbarjih, predstavljale le še neke vrste fiktivno enoto, katere namen je bil odmerjanje in pobiranje dajatev, medtem ko so bile dejanske gospodarske enote (kmetije) sestavljene iz enega ali več delov ene ali več izvornih hub na način, ki mu je izjemno težko slediti. Pri tem velja omeniti še kajže in podruštva, to so novejše gospodarske enote, ki so lahko s časom prerasle v srednje ali večje kmetije in obsegale nova ter obenem starejša zemljišča, torej taka, ki so izvorno pripadala kaki hubi. Poročilo elaborata Franciscejskega katastra za Rodik iz leta 1830 nam zariše končno sliko, ki je povsem skladna s tovrstnim razvojem: »Zemljišča so vsa v rokah kmetov, ki jih obenem lahko povsem prosto prodajo in z njimi počnejo karkoli se jim zljubi, s tem da morajo zemljiškemu gospostvu plačati deseti denar ob vsaki transakciji [...] Zemljišča so bila [nekoč] razdeljena na 19 hub in 1/2, ki so bile zatem razdeljene med 85 gospodarjev« (AS T, CF, SE, 619/2, Oec S/5).

Omenjenega števila hub ni razumeti kot število kmetij oziroma gospodinjstev, temveč kot seštevek uradno zaznanih celih hub in njihovih deležev po (zabeleženih) delitvah. Kataster sicer ne navaja vira, po katerem povzema podatek o 19,5 hubah, a je ta na las podoben tistemu iz urbarja iz leta 1400, ki navaja 18 hub, in iz urbarja iz leta 1574, ki v Rodiku našteje 19 hub, vključno s tisto, ki se je nahajala na Kozini. V štirih primerih slednji urbar zazna (uradno) delitev hub na polovice, poleg teh pa beleži še 14 enot, 
opredeljenih kot Untersassen: ${ }^{11}$ to so podružniki, družbeni sloj skoraj brez zemlje. ${ }^{12}$ Ker starejši urbar iz leta 1524, prvi iz habsburškega obdobja, ne navaja nobenega podružnika (Cova 2009, 136-137), lahko pojav tega družbenega sloja ter gospodarski razvoj in demografsko rast, ki ju izpričuje, umestimo v obdobje sredi 16. stoletja (med 1524 in 1574). V urbarju iz leta 1574 sta nadalje pri treh hubah, navedenih kot celih, zabeležena po dva solastnika, kar velja tudi za eno od polovičnih hub (Peršolja 2009, 26-27). Tovrstne navedbe lahko tolmačimo kot znak za to, da imamo $v$ teh primerih opraviti z dvema ločenima gospodinjstvoma, ki sta obdelovala vsako svoj delež uradno nedeljene hube oz. njene polovice. Če povzamemo, zadnji razpoložljivi urbar naniza 15 celih in 8 polovičnih hub, to je 23 hubnih enot, ter implicitno še dodatne 4 gospodarske enote znotraj uradno nedeljenih enot, in 14 "podruštev«. To pomeni, da je bilo leta 1574 uradno zabeleženih 37 enot in implicitno še 4, to je skupaj 41, ki jih moramo razumeti kot najmanjše možno število dejanskih gospodarskih enot oziroma gospodinjstev (zaradi možne in verjetne prikrite notranje delitve hub, ki je sicer, kot smo že navedli, zanesljivo izpričana pol stoletja kasneje, leta 1620). Čeprav utegne biti težko slediti vsem tem številkam, velja poudariti njihov osnovni namen in sporočilo, in sicer kako je že za leto 1574 mogoče ugotoviti, da je bilo v skupnosti Rodik dejanskih gospodarskih enot bistveno več, kot na prvi pogled kaže v tedanjem urbarju navedeno število 19 hub. Bilo jih je vsaj dvakrat toliko.

Ali je v tovrstni stvarnosti, pri vseh teh neznankah in bolj ali manj vidnih ter nevidnih spremenljivkah smotrno tvegati časovno zamudno in tehnično zahtevno izvedbo retrogradne analize? Vsaj zaenkrat sem si odgovoril nikalno in se na podlagi posvetovanja z Andrejem Pleterskim odločili za poenostavljeno analizo posestne strukture zemljišč in bivališč izključno na podlagi Franciscejskega katastra ter omejeno na samo osrednje rodiško polje. ${ }^{13}$ Polje namreč zajema najboljša in najrodovitnejša zemljišča, zaradi česar je razumna hipoteza, da predstavlja izvorno jedro obdelovalnih zemljišč še iz časa nastanka vasi. Tako interpretacijo zagovarja t.i.

\footnotetext{
${ }^{11}$ Peršolja (2009, 26-27). V tej publikaciji se za ta novoreformirani urbar gospostva Švarcenek navaja datacija 1576, v Cova (2009) pa 1574. Tu uporabljamo slednjo datacijo, ki jo potrjuje tudi izvleček iz švarceneškega urbarja iz leta 1574, spisan istega leta v Ljubljani, ki v Rodiku prav tako navaja 19 "celih hub« in 14 "podružnikov" (S tL A, Iö H K S, 91/14/7); v tem dokumentu je Rodik opredeljen kot "vas ali župa«, ki ji pripada tudi 11 hub in 8 podružnikov v vasi Kačiče, kolikor jih je v slednjem naselju sodilo pod švarceneško gospostvo.

${ }^{12}$ O podružnikih, posebej na Krasu, glej Panjek (2015/2016), s tam navedeno literaturo.

${ }^{13} \mathrm{Na}$ tem mestu se želim zahvaliti Andreju Pleterskemu za prijazne nasvete.
} 
»teorija o osrednjih zemljiških jedrih, ki pravi, da je imelo naselje sprva sorazmerno malo obdelane zemlje, in to v neposredni bližini, navadno na posebno ugodnih tleh, ko pa se je večalo, so v obdelovanje pritegnili nova zemljišča«. ${ }^{14}$

Ta tesna vzročna povezanost med lokacijo agrarne zemlje in naselij je bila na Krasu še posebej izrazita, in sicer ne glede na značilen dvojni, vzporedni naselitveni model $\mathrm{z}$ naselbinsko lokacijo na vrhu griča in obenem $\mathrm{v}$ dolini, ki se je uveljavil najkasneje do rimskega časa (Slapšak 1999).

Kot lokacijska determinanta utrjenih naselij železne dobe na Krasu izstopa bližina in dostopnost kvalitetne obdelovalne zemlje. Agrarne niše s primernimi obdelovalnimi površinami so v kraškem okolju izrazito omejene in razpršene, železnodobna mreža utrjenih naselij pa nadzoruje vse pomembnejše danes aktivne niše. Če odmislimo odstopanja zaradi nadzorne in obrambne lege [...], so $\mathrm{v}$ razmerju do naselbinskih lokacij območja poljedelske rabe vedno središčna. [Slapšak 2003, 244]

To velja tako za višinska kot nižinska naselja, kar "poudari pomen agrarnih virov kot odločilnega kriterija«, pri čemer se tudi »sodobna« naselja v številnih primerih locirajo ob prazgodovinske agrarne niše, kar velja tudi za naš primer - Rodik. ${ }^{15}$

Nedvomno dejstvo je, da se v 1. tisočletju pr.n.š. na Krasu oblikujejo prostorske enote [...] in to tako, da omogočajo racionalno izkoriščanje zelo omejenih območij obdelovalne zemlje v regiji. Ta struktura tako temeljito opredeli meje in možnosti subsistenčne ekonomije v regiji, da [bo] tudi kompletna menjava prebivalstva [...] aktivirala iste agrarne niše in novi naseljenci bodo prednostno aktivirali že vzpostavljene naselbinske lokacije. [Slapšak 2003, 247]

Sklepamo lahko, da naravne značilnosti Krasa dajejo posebno podporo teoriji osrednjih zemljiških jeder, čeprav je treba obenem upoštevati dejstvo, da kmetijska raba kraškega prostora zahteva stalno, sprotno, neutrudno prilagajanje in ohranjanje s strani človeka.

Območje Rundiktov, katerih center je bilo naselje Ajdovščina nad Rodikom, je sicer bilo bistveno širše od območja kasnejše vaške skupnosti Ro-

\footnotetext{
${ }^{14}$ Pleterski (2011, 14), ki se opira na Ilešiča (1950, 48-49).

${ }^{15}$ Slapšak $(2003,244)$, posebej za Rodik opomba št. 7 in str. 248.
} 
dik, kakršno izkazuje Franciscejski kataster (Slapšak 1997, 35). Kljub temu lahko jedro rodiške "agrarne niše«, to je najboljša zemljišča v niši, v primeru samega naselja rodiške Ajdovščine identificiramo $z$ "rodiškim poljem«, ki ga bomo v nadaljevanju postavili v središče naše pozornosti. Z vidika namena tega prispevka morda ni odveč opozoriti še na pisno izpričani način poteka naselitve Slovanov $v$ ta prostor. $V$ mislih imam znameniti rižanski placit iz leta 804, ki je med drugimi vprašanji urejal dostop do naravnih virov med obalnimi mesti in slovanskim prebivalstvom $\mathrm{v}$ zaledju. Prostor, ki ga je placit obravnaval, je poleg istrskega polotoka nedvomno obsegal tudi vsaj del Krasa in Brkinov, kolikor sta pripadala tržaškemu numerusu. ${ }^{16}$ "Na našo zemljo [je] naselil Slovane. Ti orjejo na naših njivah in na naših krčevinah, kosijo na naših travnikih, pasejo na naših pašnikih.«(Krahwinkler 2004, 90) Relevantno sporočilo je tu to, da so se Slovani posluževali enakih vrst rabe okolja, kot so se jih ljudje pred njimi (Panjek 2015b, 99). V rodiškem primeru bi to pomenilo, da so obdelovali tamkajšnje rodovitno polje, kar je v sozvočju z že navedeno Slapšakovo interpretacijo dolgega trajanja, to je da na Krasu novi prebivalci aktivirajo »iste agrarne niše».

Za namen naše analize smo sestavili podatkovno bazo, $\mathrm{v}$ kateri smo združili informacije in podatke iz dveh katastrskih seznamov, in sicer posestnikov stavbnih parcel in posestnikov kmetijskih zemljišč (1820; A S T, CF, SE 618/2, P G P in 618/4, P B P). Na katastrskem zemljevidu naselja Rodik smo začrtali območja petih vaških četrti, to so Podluza, Plajner, Ulica guranja, Ulica dulanja in Babenski kraj. Vsako stavbno parcelo smo povezali s hišno številko in jo na tej podlagi povezali z zemljiškimi parcelami, ki so pripadale vsaki hišni številki in odgovarjajočemu gospodarju na območju rodiškega polja. Na podlagi katastrskega zemljevida smo »širše« območje polja zamejili na parcele, ki so se nahajale na območjih z ledinskimi imeni "Strede Putti«, »Pod Doze«, »Pod Nisauza«, »Cherwizza«, »Pod Wasu«, »Per Kleni«, »Per Billi«, »Kankouze« in »Standerouze«. Tako je vsak gospodar v naši bazi dobil svoj seznam zemljiških parcel na "širšem" območju polja.

Prvi rezultat, zanimiv za namen te analize, ki smo ga pridobili na tej točki, je sledeči. Izkazalo se je, da nihče izmed bivajočih na Kozini ni posedoval nobene parcele na "širšem " rodiškem polju, izmed zunanjih kmetov pa le dva, vsak po eno. Med družinskimi poglavarji, stanujočimi v Rodiku, pa le eden ni posedoval niti ene parcele na širšem rodiškem polju.

V naslednjem koraku smo vse lastnike zemljiških parcel razvrstili na

${ }^{16} \mathrm{O}$ teritorialnem obsegu placita glej Pleterski (2005) in Žitko (2005). 
Preglednica 8 Posest parcel na širšem in ožjem rodiškem polju po vaških četrtih in gospodinjstvih

\begin{tabular}{|c|c|c|c|c|c|c|}
\hline \multirow[t]{2}{*}{ Vaška četrt } & \multirow{2}{*}{$\begin{array}{r}\text { Število } \\
\text { gospodinjstev }\end{array}$} & \multicolumn{2}{|c|}{ Širše polje* } & \multicolumn{3}{|c|}{ Ožje polje† } \\
\hline & & (1) & $\overline{(2)}$ & (1) & (2) & (3) \\
\hline Ulica guranja & 16 & 107 & 6,69 & 57 & 3,56 & 4,0 \\
\hline Ulica dulanja & 8 & 51 & 6,37 & 30 & 3,75 & 3,0 \\
\hline Babenski kraj & 23 & 149 & 6,04 & 62 & 2,70 & 3,0 \\
\hline Podluza & 16 & 64 & 4,00 & 28 & 1,75 & 1,5 \\
\hline Plajner & 16 & 103 & 6,44 & 38 & 2,37 & 2,0 \\
\hline Skupaj & 79 & 474 & 6,00 & 215 & 2,72 & 3,0 \\
\hline Stari Mlin & 1 & 6 & 6,00 & 2 & 2,00 & - \\
\hline Skupnost Rodik & 1 & 3 & 3,00 & 3 & 3,00 & - \\
\hline Zunanji lastniki & 4 & 4 & 1,00 & 4 & 1,00 & - \\
\hline Skupna vsota ali povprečje & 85 & 487 & 5,73 & 242 & 2,85 & - \\
\hline
\end{tabular}

Opombe Naslovi stolpcev: (1) skupno število parcel, (2) povprečno število parcel na gospodinjstvo, (3) mediana parcel na gospodinjstvo. * Strede Putti, Pod Doze, Pod Nisauza, Cherwizza, Pod Wasu, Per Kleni, Per Billi, Kankouze, Standerouze. † Cherwizza, Pod Wasu, Per Kleni, Per Billi.

podlagi njihovega bivališča $\mathrm{v}$ eni od petih vaških četrti, za vsakega posebej našteli število zemljiških parcel na »širšem" rodiškem polju, zatem pa na tej podlagi izračunali skupno število istih parcel v vsaki četrti posebej ter povprečja parcel na gospodinjstvo v vsaki četrti posebej. Povprečja so tu relevantnejša, ker se je število gospodinjstev razlikovalo od četrti do četrti, saj so nekatere večje in druge manjše, in z njim tudi skupno število parcel. Vaške četrti, kjer so imela gospodinjstva v povprečju največ parcel na širšem polju, so bile Plajner, Ulica guranja in Ulica dulanja; podatki so si tu precej podobni, razpon je majhen (med 6,37 in 6,69 parcele). V najmanjšem številu so jih povprečno imela gospodinjstva $v$ Podluzi, in sicer več kot tretjino manj (4 parcele).

A slika se nam precej spremeni in bistveno razbistri, če upoštevamo le zemljiške parcele na »ožjem « rodiškem polju, ki sovpada z območjem, kjer se je po Franciscejskem katastru nahajala obdelovalna zemlja najboljše kakovosti. Zato bi to območje utegnilo sovpadati z jedrom izvornih njivskih površin. V Dulanji ulici in Plajnerju so vsa gospodinjstva razpolagala z vsaj eno njivo na ožjem polju. $Z$ naskokom največje povprečno število njivskih parcel na ožjem polju so imela gospodinjstva iz Dulanje $(3,75)$ in iz Guranje ulice $(3,56)$, kjer je bilo povprečje tudi bistveno višje od skupnega za celotno vas (2,27 parcele). Tudi na ožjem polju daleč najnižje povprečje iz- 
Preglednica 9 Stavbno premoženje imetnikov največjega števila parcel (preko 5) na ožjem polju

\begin{tabular}{|c|c|c|c|c|c|c|}
\hline$(1)$ & (2) & (3) & (4) & Stavba & Hlev & Gospodar \\
\hline 7 & $\begin{array}{l}\text { Ulica } \\
\text { guranja }\end{array}$ & 11 & 62 & $\begin{array}{l}\text { Stanovanjsko in gospo- } \\
\text { darsko poslopje }\end{array}$ & $\begin{array}{l}\text { Prostora za } 2 \text { glavi go- } \\
\text { veda, } 1 \text { prašiča }\end{array}$ & $\begin{array}{l}\text { Zhebochin Stephan, } \\
\text { vulgo Kataz (Kotež*) }\end{array}$ \\
\hline 6 & $\begin{array}{l}\text { Ulica } \\
\text { guranja }\end{array}$ & $\begin{array}{l}82 \\
88, \\
89 \\
91\end{array}$ & 72 & $\begin{array}{l}\text { Dve stanovanjski po- } \\
\text { slopji; } 1 \text { stanovanjsko } \\
\text { poslopje z dvoriščem; } \\
2 \text { dvorišči }\end{array}$ & $\begin{array}{l}\text { 1-nadstropno stano- } \\
\text { vanjsko poslopje, pro- } \\
\text { stora za } 4 \text { glave go- } \\
\text { veda, } 2 \text { prašiča; doda- } \\
\text { tna hiša in dvorišče }\end{array}$ & Bobuder Martin \\
\hline 6 & $\begin{array}{l}\text { Ulica } \\
\text { dulanja }\end{array}$ & 70 & 78 & $\begin{array}{l}\text { Stanovanjsko in gospo- } \\
\text { darsko poslopje }\end{array}$ & $\begin{array}{l}\text { 1-nadstropna stavba, } \\
\text { prostora za } 2 \text { glavi go- } \\
\text { veda, } 4 \text { ovce, } 1 \text { prašiča }\end{array}$ & $\begin{array}{l}\text { Zhebochin Jakob, } \\
\text { vulgo Mangecz (Mar- } \\
\text { kuč }{ }^{*} \text { ) }\end{array}$ \\
\hline 6 & $\begin{array}{l}\text { Ulica } \\
\text { dulanja }\end{array}$ & 68 & 76 & $\begin{array}{l}\text { Stanovanjsko in gospo- } \\
\text { darsko poslopje }\end{array}$ & $\begin{array}{l}\text { 1-nadstropno stano- } \\
\text { vanjsko poslopje, pro- } \\
\text { stora za } 5 \text { glav goveda, } \\
35 \text { ovc, } 4 \text { prašiče }\end{array}$ & $\begin{array}{l}\text { Berneicez Valentin, } \\
\text { vulgo Herbertz (Gr- } \\
\left.\text { bec }^{*}\right)\end{array}$ \\
\hline 6 & $\begin{array}{l}\text { Ulica } \\
\text { dulanja }\end{array}$ & 66 & 74 & $\begin{array}{l}\text { Stanovanjsko in gospo- } \\
\text { darsko poslopje }\end{array}$ & $\begin{array}{l}\text { Prostora za } 2 \text { glavi go- } \\
\text { veda, } 2 \text { ovci, } 1 \text { prašiča }\end{array}$ & $\begin{array}{l}\text { Zhebochin Gertrut } \\
\left(\text { Jera }^{*} \text { ), dodano Stefan }\right. \\
\text { (njen brat, Francov*) }\end{array}$ \\
\hline
\end{tabular}

Opombe Naslovi stolpcev: (1) Število parcel na ožjem polju, (2) vaška četrt, (3) številka stavbne parcele, (4) hišna številka. * Identificirane osebe z vzdevki po Peršolja (2009).

kazujejo gospodinjstva v vaški četrti Podluza (1,75 parcele), a tu so z malo njivskimi parcelami razpolagala tudi tista $v$ četrti Plajner $(2,37)$. V obeh primerih (širše in ožje polje) pa je bila četrt Babenski kraj točno v vaškem povprečju (preglednica 8 ).

Zaradi ugotovljenega morda niti ne preseneča, da so se vse kmetije, ki so posedovale preko pet njivskih parcel na ožjem rodiškem polju, nahajale v vaških četrtih Guranja in Dulanja ulica (preglednica 9). Brez parcel na ožjem polju pa je bilo 7 rodiških gospodinjstev, in sicer tri v Podluzi, ki tudi s tega vidika izkazuje najmanjšo razpoložljivost najboljše zemlje, dve v Babenskem kraju in še dve v Guranji ulici.

\section{Prva hipoteza na stičišču zgodovine in ljudskega izročila}

Na podlagi predpostavke, da posest večjega števila parcel na najrodovitnejšem območju vaškega zemljiškega jedra, to je na ožjem polju, kaže na izvor teh kmetij iz prvotnih hub, bi lahko sklepali, da so se hubne domačije $v$ drugi polovici 16. stoletja nahajale v vaških četrtih Guranja in Dulanja ulica ter Babenski kraj. Tako branje je skladno z rekonstrukcijo in navedbami Jasne M. Peršolja (2009), ki hube iz reformiranega urbarja in njihove gospo- 
darje povezuje s kasnejšimi rodbinami v Rodiku, pri čemer navaja delitve in dedovanja, in sicer na podlagi kombinacije pisnih in ustnih virov. Skladnost obeh rezultatov bi lahko bila zadostna osnova za hipotezo, da so se rodiške hubne domačije nahajale v navedenih vaških četrtih, kar bi bilo po svoje logično tudi z logističnega vidika, saj se nahajajo najbližje vaškemu polju. V rekonstrukcijo procesa delitev hub skozi stoletja pa ne bomo šli, ne le zaradi tega, ker bi se lahko oprli samo na Peršoljine navedbe, brez lastnega izvirnega prispevka, temveč predvsem zaradi že omenjenega opažanja cenitvenih komisarjev gospostva, da nihče izmed gospodarjev hub iz urbarja 1574 leta 1620 ni bil več pri življenju, da so medtem "nekatere hube tri- ali štirikrat prešle $\mathrm{v}$ druge roke in da jih je bila večina tudi razdeljena na več delov« (Panjek 2002, 51; Cova 2009, 117). Ta informacija se nam zdi zadosten razlog za opreznost pri povezovanju starih hub s kmetijami v 17., 18. in končno na začetku 19. stoletja, to je v času nastanka Franciscejskega katastra, ki je naše izhodišče. $V$ vsakem primeru velja opozoriti še na to, da priimki posestnikov, navedeni v katastru, ne ustrezajo tistim iz urbarja, ker so se medtem nekateri spremenili (npr. iz vzdevka), v drugih primerih pa so nov priimek prinesli ti, ki so se primožili na kmetijo brez moškega dediča, kot to na več mestih nazorno prikaže Peršolja.

$\mathrm{Na}$ osnovi iste izhodiščne predpostavke bi bilo na drugi strani mogoče sklepati, da v vaških četrtih, katerih hišni gospodarji v Franciscejskem katastru izkazujejo najmanjše število parcel na rodovitnem polju, izvorno ni bilo hubnih domačij, kar se sklada tudi z logistično situacijo, saj se Podluza in Plajnar nahajata višje v bregu, najdlje od polja. Tudi v tem primeru je tovrstno interpretacijo mogoče potrditi z informacijami, ki jih na več mestih navaja Peršolja, in sicer da sta bili Podluza in Plajnar četrti »obrtnikov« in »kajžarjev“ (podružnikov), torej gospodinjstev z manj zemlje in vsaj izvorno takih, pri katerih kmetovanje ni bilo osrednji vir dohodka ter niso izhajali iz prvotnih hub, temveč iz podružnikov in kasnejših priseljencev. Povzemam nekaj tovrstnih navedb (Peršolja 2009, 41, 82, 154, 189-19o, 198, 205, 305):

Kovačevi so se naselili v Podluzi, med kovačema Krameričem (Frižcem) in Marinčičem, kjer so stanovali rodiški obrtniki in kajžarji. [...] Prej so Marinščevi imeli hišo v Podluzi [...] niso imeli zemlje [...] so bili kovači. Hišo naj bi sezidali Marinščevi na najpomembnejši križpoti in ob ostalih obrtniških hišah. Kovači so bili tam v Podluzi še Kovačevi in Frižčevi. Sosedje Brcelovi so bili kamnoseki in stavbarji. [...] Frižčevi so stanovali nad Plajnarjem, kjer so živeli rodiški obr- 
tniki. Bili so kovači. [...] V urbarju švarceneške gosposke iz leta 1576 je zapisano, da je med rodiškimi bajtarji takrat živel kajžar s priimkom Žnidar, po poklicu naj bi bil kovač. [.. .] Po tem sodimo, da je bil tisti Žnidar bajtar na Plajnarju. [...] Primož Babič [...] je bil krojač. [...] Naselil se je pri obrtniku (kajžarju) Žnidarčiču na Plajnarju in se leta 1660 obvezal, da bo Bratovščini poplačal njegove dolgove. [...] Marinščev Anton je bil obrtnik in se je preselil v Podluzo. [...] Razen Pećunovih in Madalenčičevih, ki so bili na Plajnarju, kjer niso živeli kmetje, ampak obrtniki in bajtarji, [...] so vsi Babiči živeli v Babenskem kraju.

Babenski kraj pa je bila vaška četrt, v kateri so se po Peršolji nahajale nekatere domačije prvotnih hub. Avtorica posebej poudarja, kako je Leonard Babič »s svojimi rodovnimi vejami osnoval Babenski kraj«. Vaško izročilo pa pripoveduje, da so "Babiči pribežali v Rodik pred Turki. Najprej so bili trije bratje."(Peršolja 2009, 280, 305-306, 310) Trije Babiči so v urbarju 1574 dejansko navedeni kot nosilci dveh hub. Ker je število hub leta 1400 in leta 1574 enako (18 v Rodiku plus ena na Kozini), lahko sklepamo, da so Babiči (kot priseljenci ali pa tudi ne) prevzeli že obstoječe in opustele hube, ne pa vzpostavili novih. Nespremenjeno število hub v Rodiku v obdobju 1400-1574 bi lahko pomenilo, da so na območju Babenskega kraja že leta 1400 obstajale domačije, razen če dopustimo možnost, da se je vseh (vsaj) 18 hubnih domačij nahajalo na razmeroma majhnem območju Guranje in Dulanje ulice, kar bi pomenilo podobno gostoto gospodinjstev kot štiri stoletja kasneje, za časa Franciscejskega katastra. Tega ni mogoče povsem izključiti, kot bomo še videli, zato obstaja možnost, da Babiči niso »osnovali« vaške četrti Babenski kraj, temveč so jo s svojo razvejano rodbino morebiti poimenovali. Ne glede na to pa je iz Peršoljinega dela razvidno, da so v četrti Babenski kraj poleg domačij, ki so izvirale iz hub iz druge polovice 16. stoletja, skozi čas nastajale nove, in sicer ne le zaradi delitev, temveč so se vanje naseljevali tudi novi prišleki.

V skladu z navedenim lahko oblikujemo prvo hipotezo, da se je Rodik v socialnem in gospodarskem pogledu delil na dva dela, pri čemer so bili v treh nižje ležečih vaških četrtih Guranja in Dulanja ulica ter Babenski kraj koncentrirani večji kmetje in kmetije, ki so izvirale iz prvotnih hub (pri čemer je bil Babenski kraj bolj pisane socialne sestave zaradi kasnejših prišlekov in delitev kmetij), medtem ko v dveh višje ležečih četrtih Podluza in Plajnar najdemo gospodinjstva z manj dobre zemlje, ki so vsaj deloma izvirala iz podružnikov. Ker so se podružniki v Rodiku pojavili v obdobju med 


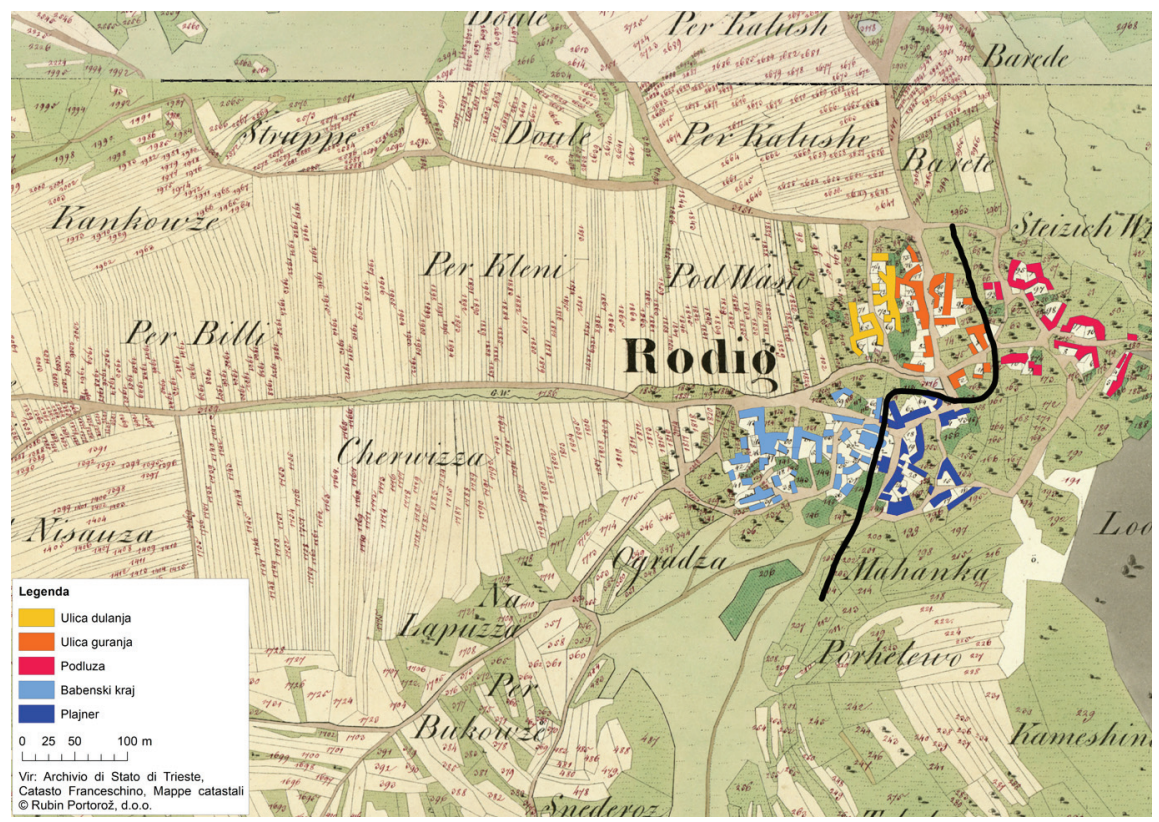

Slika 4 Vaške četrti in delitev vasi v skladu s prvo hipotezo

urbarjema iz let 1524 (ko jih še ni bilo) in 1574 (ko jih je bilo že 14), je mogoče tvegati nadgradnjo te hipoteze v smislu, da sta četrti Podluza in Plajner mlajšega nastanka ali vsaj poznejšega razvoja, Ulici in Babenski kraj pa starejšega izvora. To seveda ne prejudicira drugačne naselitvene slike v srednjeveškem obdobju, saj bi bili območji Plajnarja in Podluze lahko že poseljeni, preden sta postali podružniški in »obrtniški« četrti.

\section{Druga hipoteza na stičišču zgodovine in ljudskega izročila}

A kaj ko o prostorskem razvoju vasi obstaja krajevno ljudsko izročilo, ki se precej razlikuje od pravkar navedene hipoteze. Kot je pri takih rečeh pravilo, je eden od problemov v tem, da lokalni »dolgi spomin« ne pozna časovne perspektive (Zonabend 1993). Poglejmo, kaj pravi izročilo, obogateno $z$ novejšim znanjem, kaj se da iz njega razbrati, ali mu je mogoče najti oporo v naših (gotovo ne povsem zadovoljivih) podatkih in morda zaslediti kako skladnost s tem, kar je bilo že povedanega zgoraj.

V Rodiku iz roda v rod pripovedujejo, da so prvo cerkvico sezidali v Podluzi. Bila je majhna in je bila na kraju, kjer je bil pozneje Bošnarjev hlev. Bila je posvečena sv. Petru. Prav tako naj bi bil portal 
iz stare cerkvice vzidan v Bošnarjevi hiši. Koliko je to res, ne vemo. Res pa je, da je imela Bošnarjeva hiša lep gotski portal. [...] Vas se je iz Podluze širila proti polju in je tako nastala Guranja ulica, nato še Dulanja ulica in Plajner. Nazadnje se je vas raztegnila pod Breg v Babenski kraj. Med Plajnarjem in Babenskim krajem so Rodičani na mestu, kjer je tudi sedaj cerkev, sezidali novo [...] in jo posvetili sv. Trojici. V15. in 16. stoletju je bilo v naših krajih veliko vojska in drugih nadlog. [...] Število prebivalstva se je zmanjšalo, vas pa je opustela. Cerkev je propadala in propadla. Ko so se razmere nekoliko uredile, so se v vas naselile nove družine. Rodičani so v začetku 17. stoletja začeli popravljati, večati in lepšati svojo cerkev. [...] Rodičani so vklesali za letnico obnove cerkve sv. Trojice letnico 1647. [Peršolja in Pregelj 1997, 94-95]

V luči tega krajevnega ljudskega izročila razvojno zaporedje, ki smo ga predstavili zgoraj kot prvo hipotezo, izgleda postavljeno na glavo, kakor tudi identifikacija starejšega jedra vasi, saj se prestavlja v četrt Podluzo, ki naj bi bila po prejšnji rekonstrukciji kasnejšega, podružniškega izvora. Po drugi strani pa je tako zaporedje, ki starejši del vasi vidi v Podluzi, Guranji in Dulanji ulici, v pomenljivem sozvočju s poimenovanjem dela rodovitnega polja pod temi četrtmi z ledinskim imenom »Pod vasjo«, kakor je razvidno iz map Franciscejskega katastra, ki se je lahko prijelo le pod starejšim jedrom vasi. To pa sta po obeh hipotezah ravno Guranja in Dulanja ulica, čeprav tokrat $\mathrm{z}$ dodatkom Podluze višje v bregu.

Iskreno povedano sem ob prvem natančnejšem pogledu na tloris Rodika, kakor je narisan v Franciscejskem katastru, verjetno starejše jedro vasi zagledal prav na območju Guranje in Dulanje ulice, in sicer zaradi bolj izstopajoče tipične strukture starejših kraških domačij, ki so skozi čas z dodajanjem stavb in prizidkov težile $k$ temu, da $z$ dveh ali več strani obdajajo dvorišče. Resnici na ljubo je tak vzorec v par primerih viden tudi v Podluzi in $\mathrm{v}$ Babenskem kraju, medtem ko ga večina stavbnih tlorisov v samem Babenskem kraju in na Plajnarju ne izkazuje.

$\mathrm{Ni}$ povsem jasno, ali sta širitev vasi na levo stran ulice in potoka (gledano $z$ vrha vasi proti polju), ki je tekel ob njej, to je na območje Plajnerja in Babenskega kraja, ter prestavitev vaške cerkve $\mathrm{v}$ času pred demografskim upadom zaradi turških vpadov in vojn (posebej med drugo polovico 15. in začetkom 16. stoletja, kolikor ve povedati zgodovinopisje) strokovni vložek sodobnega znanja ali pa ta okvirna datacija izvira neposredno iz ljudskega izročila. Zgoraj smo namreč navedli, kako naj bi po isti avtorici 
Babenski kraj ustanovili pripadniki rodbine Babič, pribežniki z juga pred turškim pritiskom, kar je spet mogoče postaviti v obdobje med drugo polovico 15. in začetkom 16. stoletja. Ostajam mnenja, da je verodostojneje, da se je po njih vsaj v zametkih obstoječa četrt le preimenovala, ne pa tudi na novo ustanovila, ali mogoče na novo postavila po opustelosti. V vsakem primeru zveni logično, da je širitvi vasi sledila (v neznanem času) postavitev nove cerkve v novo središčno pozicijo razširjenega naselja, nekako na stičišču vseh vaških četrti, kar bi se skladalo z navedeno Peršoljino rekonstrukcijo, da je Rodik kasnejše razsežnosti (vseh pet vaških četrti) vsaj v grobem dobil že pred močnejšimi turškimi vpadi v tem delu Primorske, torej pred sredino 15. stoletja in morda že pred letom 1400, saj nam tedanji urbar že našteva 18 hub. Je pa res, da bi bilo z vključeno Podluzo mogoče imeti vseh (vsaj) 18 hubnih domačij na območju same Guranje in Dulanje ulice s Podluzo. Negotovost ostaja in za skoraj vsako hipotezo je moče najti protiargument, kar je posledica pomanjkanja zanesljivejših podatkov.

Glede na tipologijo virov in analize, ki smo jo ubrali, bomo poskusili preveriti, ali je taki delitvi med morebitnim starejšim delom vasi na levi strani vaške ulice in potoka (Guranja in Dulanja ulica ter Podluza) in novejši na drugi strani (Babenski kraj ter Plajnar) mogoče najti kako podlago družbeno-gospodarskega značaja. Poskusil sem združiti vse tovrstne kazalnike, kolikor mi jih je uspelo oblikovati v tem prispevku, in preveriti, ali mi je kaka ločnica oziroma povezava ostala prikrita. Na ta način bo obenem preverjena prvotna hipoteza, da sta Ulici in Babenski kraj po izvoru in posesti boljših njiv bolj »kmečki« kot Podluza in Plajner. V enotni preglednici so združeni podatki o tipologiji zasebnih stavb, zmogljivosti hlevskih prostorov in njivskih parcel na boljšem polju ter prikazani za vsako vaško četrt posebej v obliki odstotkov ter povprečij na gospodinjstvo. Kar pridobimo na ta način, je - sicer precej grob in posreden - prikaz premožnosti. Dejstvo, da je poslopje enonadstropno, ne pomeni nujno, da je gospodinjstvo bogatejše, saj je lahko stavbna parcela majhna in se zato stavba razvija $\mathrm{v}$ višino. Podobno je z zmogljivostjo hlevov, ki še ne pove, ali so bili tudi dejansko zapolnjeni z živino. Poleg tega naši kazalniki poudarjajo kmetijski dejavnik in zanemarjajo neagrarne oblike premoženja ter dejavnosti, kakor tudi večje ali manjše zadolženosti in podobnih dejavnikov. Kljub tem omejitvam pa nam omogočajo, da pridobimo nekoliko širšo sliko od tiste, ki sloni le na boljših njivah (preglednica 10).

Dosedanja slika, bazirana le na posesti boljših zemljiških parcel, se nam spremeni zlasti v treh pogledih. Kot prvo se zmanjša razkorak v premožnosti med četrtma Plajner in posebej Podluza ter ostalimi, saj izkazujeta 
Preglednica 10 Združeni kazalniki premožnosti gospodinjstev po vaških četrtih

\begin{tabular}{|c|c|c|c|c|c|c|c|}
\hline \multirow[t]{2}{*}{ Vaška četrt } & \multicolumn{3}{|c|}{$\begin{array}{l}\text { Delež tipologije zasebnih } \\
\text { stavb (v odstotkih) }\end{array}$} & \multicolumn{3}{|c|}{$\begin{array}{l}\text { Povprečna zmogljivost } \\
\text { hlevov na gospodinjstvo } \\
\text { (število glav) }\end{array}$} & \multirow[t]{2}{*}{ (7) } \\
\hline & (1) & (2) & (3) & (4) & (5) & (6) & \\
\hline Ulica guranja & 76,5 & 17,6 & 5,9 & 2,6 & 6,4 & 1,3 & 3,56 \\
\hline Ulica dulanja & 37,5 & 37,5 & 25,0 & 2,5 & 9,0 & 1,5 & 3,75 \\
\hline Babenski kraj & 77,0 & 11,5 & 11,5 & 1,1 & 2,2 & 0,6 & 2,70 \\
\hline Podluza & 55,6 & 22,2 & 22,2 & 2,4 & 7,8 & 1,4 & 1,75 \\
\hline Plajner & 62,5 & 25,0 & 12,5 & 1,9 & 6,9 & 0,9 & 2,37 \\
\hline
\end{tabular}

Opombe Naslovi stolpcev: (1) pritlično poslopje, (2) enonadstropno stanovanjsko in pritlično gospodarsko poslopje, (3) enonadstropno poslopje, (4) govedo, (5) ovce, (6) prašiči, (7) povprečno število parcel na ožjem polju na gospodinjstvo.

precejšnje število enonadstropnih stavb, Podluza pa še zmogljivost hlevov, primerljivo s tisto v Guranji in Dulanji ulici. Zanimivo je tudi, da med obema pogojno "nekmečkima "vaškima četrtma pri vseh kazalnikih, razen pri povprečnem številu njiv na polju, Podluza prekaša Plajner. Drugič, Guranja ulica se pokaže v manj svetli luči, posebej z vidika stavbnega fonda, ki je v veliki meri pritličen, medtem ko je prostornost hlevov blizu Dulanji ulici in Podluzi. A največji odmik od dosedanje slike je ta, da se Babenski kraj izkaže kot vaška četrt, ki močno zaostaja za povprečji skoraj vseh drugih četrti in je pri večini naših kazalcev na zadnjem mestu. V Babenskem kraju najdemo najvišji delež pritličnih stavb in najmanj enonadstropnih ter najmanjše hleve za vse vrste živine, tako da gospodinjstva v tej četrti, če odmislimo njive na polju, izgledajo kot najmanj premožna. Na osnovi teh ugotovitev je videti, kot da delitev na dva dela na podlagi večje ali manjše (relativne) premožnosti morda ni potekala med nižje ležečimi in bolj kmečkimi ter višje ležečimi in manj kmečkimi četrtmi na škodo slednjih, temveč vzdolž glavne vaške ulice in potoka, kjer so se na eni strani nahajale nekoliko premožnejše četrti Dulanja in Guranja ulica ter Podluza, na drugi pa manj premožni Babenski kot in Plajner. Taka delitev sovpada s tisto iz ljudskega izročila, pri čemer bi bila starejša polovica vasi še v 19. stoletju premožnejša, in ga s tem nekako potrjuje, in to kljub notranjim procesom, ki smo jih že omenjali.

Na tej točki je mogoče tvegati novo, drugo hipotezo razvoja vasi Rodik na podlagi integracije med seboj skladnih zgodovinskih ter etnografskih elementov, kot sledi. Starejši del Rodika je tisti, ki se nahaja na desni strani vaške ulice in potoka (gledano proti polju; na severni strani), in zajema četrti 
Guranja in Dulanja ulica ter Podluza. Vas se najverjetneje že v zadnjih stoletjih srednjega veka razširi nad drugi del vaškega polja (levo od ulice), kjer so morda že locirane nekatere hubne domačije. Kot drugje na Krasu po turških vpadih novi naseljenci zasedejo opustele kmetije (konec 15.-začetek 16. stoletja) in na prejšnji ali na novi lokaciji tudi na novo zgradijo katero od opuščenih domačij, tako da je v urbarju iz leta $1574{ }^{17} \mathrm{v}$ Rodiku mogoče videti "priseljenske« priimke (s tem da Babič ni nujno priseljenski priimek, glede na izstopajoči pomen »Babe« v lokalnem izročilu). ${ }^{18}$ Krizno obdobje se počasi zaključuje in proti polovici 16. stoletja $\mathrm{v}$ skladu s splošnim trendom $\mathrm{v}$ kraškem prostoru prebivalstvo narašča, hube se delijo, takrat in $\mathrm{v}$ drugi polovici 16. stoletja pa se dodatno vzpostavljajo razmeroma številna nova gospodinjstva brez zemlje, ki se naseljujejo na srenjski zemlji (podružniki) ali stanujejo na kmečkih domačijah (gostači). Tako je v urbarju iz leta 1574 v Rodiku že okrog 40 gospodinjstev, ki domujejo na delih hub ali so podružniki. Slednji se v Rodiku naseljujejo predvsem v staro, a morda delno opustelo in po novem perifernejšo Podluzo, ob redke kmetije, ki so obstale iz preteklosti. Na ta način Podluza doživi globoko socialno spremembo, a ne glede na to globlje korenine preostalih domačij in podjetnost ter gospodarska in poročna uspešnost prišlekov omogočijo ohranitev ter morda dvig povprečne premožnosti gospodinjstev. Podoben proces zajame mlajšo četrt Plajnar, kjer gospodinjstva kljub vsemu v povprečju uspejo obdržati ali pridobiti (prek nakupov, dot, dedovanj) nekaj več parcel na polju. To niso edinstveni procesi, saj je marsikje na Krasu vidno, da so se izvorno »kajžarske« posesti po obsegu zemljišč približevale preostankom hubnih, in sicer že proti koncu 16. stoletja (Panjek 1997). Rast prebivalstva in posebej priseljevanje (npr. Karnijcev, kot je razvidno iz dela Peršolje) se od začetka 17. stoletja dalje osredotočita zlasti v Babenskem kraju, ki zaradi tega pridobi najbolj pisano socialno strukturo, kar na dolgi rok zmanjšuje koncentracijo starejših domačij in razvodeni njen »kmečki« značaj, s tem pa znižuje povprečje parcel na polju in druge kazalnike premožnosti, kot smo videli. Druga polovica 17. in prva polovica 18. stoletja predstavljata obdobje krize ali vsaj stagnacije, kar je mogoče zaznati tudi iz razmeroma visokega števila podrtij in ruševin, ki se na začetku in sredi 18. stoletja ter še kasneje najdejo po kraških vaseh, in česar ostanki so v Rodiku vidni še za časa Franciscejskega katastra (1830). Zaradi tega ni pričakovati, da bi se vas Rodik v

\footnotetext{
${ }^{17}$ Urbarja iz leta 1524, ki se hrani v arhivu v Gradcu, zaradi epidemije v letu 2020 ni bilo mogoče preveriti.

${ }^{18} \mathrm{O}$ »Babi« glej Hrobat Virloget (2010a).
} 


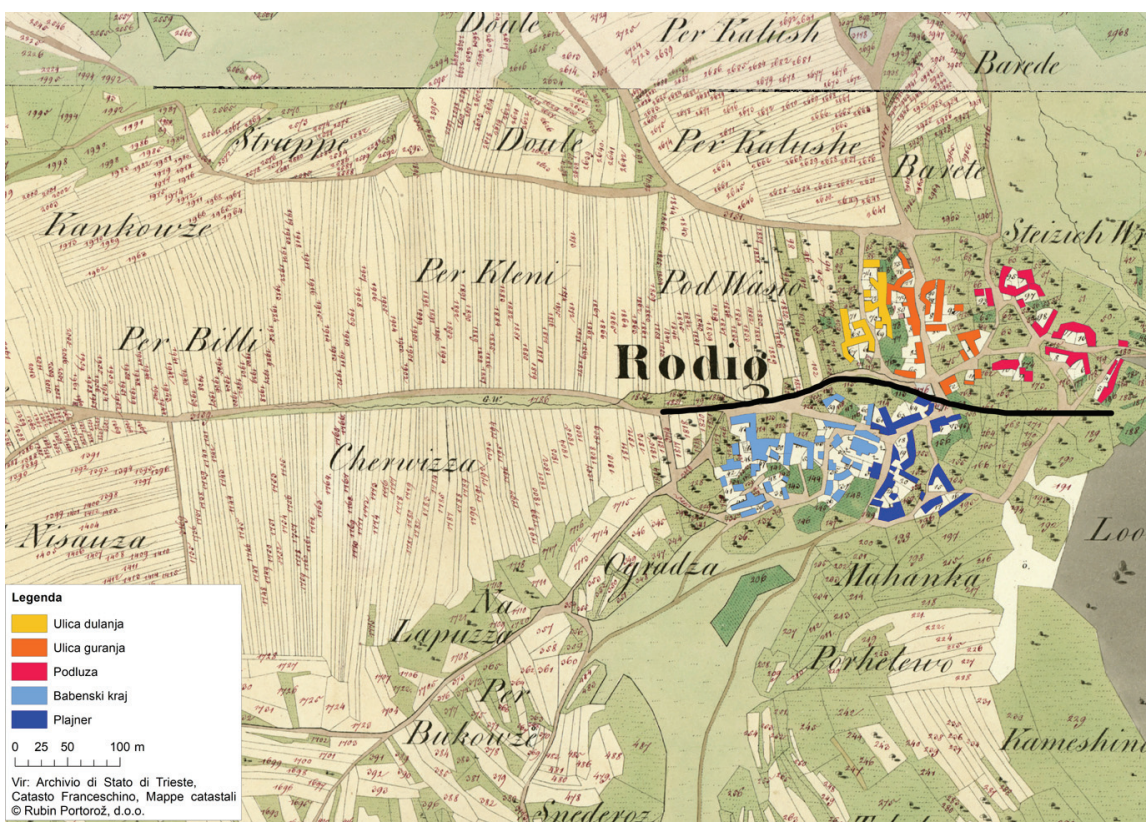

Slika 5 Vaške četrti in delitev vasi v skladu z drugo hipotezo

obdobju od polovice 17. do najmanj sredine 18. stoletja veliko širila, večala ali razvijala; tudi vplivna moč Trsta do takrat še ni bila dovolj velika, da bi podprla izrazitejši razvoj vasi v svojem zaledju.

Po teh poteh globlje korenine posameznih četrti in njihovih domačij ter posledice novejših procesov - v obliki večjega ali manjšega deleža mlajših gospodinjstev ter njihove uspešnosti - prispevajo k ohranitvi in opredelitvi delitve vasi na njen starejši in obenem premožnejši del (Guranja in Dulanja ulica ter Podluza) ter na mlajši in obenem nekoliko revnejši del (Babenski kraj in Plajner). Ta delitev sovpada $\mathrm{z}$ razdelitvijo vasi vzdolž glavne ulice in vzporednega potoka.

Druga delitev vasi, izpričana v etnoloških in folklornih virih, je Rodičane pri udejstvovanju v verskih obredih in posvetnih ritualih ter dejavnostih ločevala na dva dela. Zanimivo je, da se je v tem pogledu Rodik ločeval na del, ki sta obsegala četrti Guranja in Dulanja ulica ter Podluza na eni in Babenski kraj ter Plajner na drugi strani. Že na prvi pogled je videti, da ta delitev vasi poteka vzdolž glavne ulice (in potoka) na vasi in je torej prostorsko precej jasna in obenem enostavno razpoznavna. Obenem je povsem skladna z našo drugo hipotezo, sestavljeno z usklajevanjem zgodovinskih virov in izročila o izvoru vasi. Ob njenem upoštevanju imamo tako 
že tri dimenzije razločevanja, ki potekajo vzdolž rodiške ulice in potoka: čisto prostorska (leva in desna oziroma severna in južna stran), "stara "vas in "nova« vas ter pogojno rečeno »bogati« in »revni« del. Vsaka od teh razlik je bila lahko zadosten izvor kolektivne identitetne kohezije dveh »obrednih" skupin znotraj vasi, kaj šele vse tri obenem. To nam verjetno lahko razloži temelje te, recimo ji »obredne«, delitve, ki hkrati predstavlja četrto sovpadajočo delitev vasi na dva dela vzdolž osrednje vaške osi - ulice s potokom.

\section{Sklepne besede}

Na podlagi navedenega je druga hipoteza prepričljivejša, saj sloni na večjem številu kazalnikov, čeprav ostajamo na ravni - hipoteze. Ostajamo tudi z odprtimi vprašanji, med katerimi velja omeniti vsaj dve. Tu je najprej težavna opredeljivost časa širitve vasi na drugi breg potoka. Drugo vprašanje zadeva zelo dolgo obravnavano obdobje, v teku katerega so se kmetije, rodbine in družine delile in prepletale, gmotno dvigovale in padale, tako da je slika Rodika, ki jo dobimo na podlagi Franciscejskega katastra, le ena v nizu preštevilnih slik na filmskem traku večstoletnih dinamik na vasi, v kateri smo poskusili zaznati dolgotrajnejše strukturne značilnosti.

Za zaključek pa sta na mestu še pomislek in opozorilo. Najprej velja upoštevati, da je znotraj vaške skupnosti obstajal gost, zapleten in tesen preplet družinskih in rodbinskih povezav, in sicer tako na splošno kot tudi specifično v primeru Rodika, kot izrazito izhaja iz rekonstrukcije rodiških rodbin izpod peresa Peršolje, ki lepo pove, kako so "vsi [...] z vsemi v sorodstvu«. Sorodstvene vezi, prepletene $z$ gmotnimi interesi in trenji, pa so lahko pomemben dejavnik pri oblikovanju povezav in delitev znotraj skupnosti, ki ga tu ne moremo upoštevati, že zato, ker jih ne poznamo dovolj. A poleg teh lahko obstajajo tudi drugačne vezi, ki niso krvne, a so stkane iz samih gmotnih in socialnih interesov ter so lahko vertikalne, ki povezujejo revnejše $z$ bogatejšimi, ali horizontalne, ko združujejo pripadnike istega družbenega sloja. Tovrstne delitve v podeželski družbi niso nikakršen izjemen primer in so lahko dolgotrajne in trdožive, kar pa še ne pomeni - to želim poudariti -, da nujno koreninijo v davni preteklosti, saj se zgodovina na vasi stalno dogaja. Podoben pojav rodiškemu je Furio Bianco na primer zaznal in dokumentiral $\mathrm{v}$ karnijski vasi Fusea, kjer sta še do nedavna dva vaška tabora ločeno sedela $v$ cerkvi in si bila nasploh zoperstavljena v marsikaterem pogledu vsakdanjega življenja. Ugotovil je, da delitev izvira iz točno določenih in konkretnih dogodkov v 18. stoletju, ko so pripadniki vaške elite samovoljno spremenili pravila delovanja skupnosti in omejili dotlej veljavno možnost širšega kroga družinskih poglavarjev, 
da bi v skladu z običaji sodelovali pri odločanju o relevantnih zadevah za skupnost (Bianco 2002). Zato kljub temu, da smo vsaj navidez identificirali kar tri prekrivajoče se možne izvore rodiške »obredne« delitve, ne moremo povsem izključiti, da je tudi v rodiškem primeru nekdaj prišlo do kakega razkola znotraj skupnosti (na osnovi delitve med bogate in revne prebivalce ali med stanovalce starejšega in novejšega dela vasi, ali pa tudi ne), ki ga ne poznamo in čigar posledica je bila notranja razdeljenost. To bi bila tema za posebno raziskavo, če bi jo le pisni viri dopustili.

\section{Arhivski viri}

AS T, CF, S E: Archivio di Stato di Trieste, Catasto Franceschinio, Serie Elaborati.

468/2, Oec S/5: Naklo, 468/2, Operato d'estimo catastale del Comune di Nacla, S/5.17.20.21.

618/1, G B: Rodik, b. 618/1, Grenz-Beschreibung der Gemeinde Rodig (1820).

618/2, P G P: Rodik, 618/2, Protokoll der Grund-parcellen der Gemeinde Rodig (1818-22; 1839).

618/4, P B P: Rodik, 618/4, Protokoll der Bau-parcellen der Gemeinde Ro$\operatorname{dig}(1818-22 ; 1839)$.

619/1, Q-C S O S/4: Rodik, 619/1, Questionario sullo stato economico del comune censuario, s/4, Catastral-Schatzungs-Operat der Steuer Gemeinde Rodig (1819).

619/2, Oec s/5: Rodik, b. 619/2, Operato d'estimo catastale, s/5.17.20.21 (1830).

StLA, IöHKS: Steiermärkisches Landesarchiv, Ineeröstrerreichische Hofkammer - Sachabteilung.

91/14/7: Sch. 91, Fasz. 14, fol. 7.

\section{Literatura}

Baš, A. 1952. "K stavbnemu in zemljiškemu značaju Ljubljane v Franciscejskem katastru. "Slovenski etnograf 5:76-100.

—. 2008. "Agrarno gospodarstvo v katastrski občini Sora 1831/1832." Loški razgledi 54 (1): 95-108.

Bianco, F. 2002. „Vincoli comunitari e conflitti vicinali nella montagna carnica del '70o: Il caso di Fusea.«V B. Furio, Contadini e popolo tra conservazione e rivolta: ai confini orientali della Repubblica di Venezia tra' 400 e '8oo; saggi di storia sociale, 41-61. Videm: Forum Editrice Universitaria.

- 2011. Krvavi pust 1511: kmečki upori in plemiške fajde v Furlaniji. Koper: Založba Annales.

Blaznik, P. 1980. "Žiri v luči Franciscejskega katastra.« Loški razgledi 27 (1): 120-130. 
Britovšek, M. 1958/1959. »Uvajanje novih kultur na Kranjskem v drugi polovici 18. in prvi polovici 19. stoletja."Zgodovinski časopis 12/13:111-149.

Cova, U. 2009. La signoria di Schwarzenegg: un feudo goriziano sul carso alle porte di Trieste. Videm: Del Bianco Editore.

Drobesch, W., ur. 2013. Kärnten am Übergang von der Agrar-zur Industriegesellschaft: Fallstudien zur Lage und Leistung der Landwirtschaft auf der Datengrundlage des Franziszeischen Katasters (1823-1844). Celovec: Verlag des Geschichtsvereins für Kärnten.

Golec, B. 2010. "Zemljiški katastri 18. in 19. stoletja kot vir za stavbno, gradbeno in urbanistično zgodovino slovenskega ozemlja - 2. del.«Arhivi 33 (2): 339-396.

Hrobat Virloget, K. 2005. »Ajdi z Ajdovščine nad Rodikom. Studia mythologica Slavica 8:99-112.

- 2010a. Ko Baba dvigne krilo: prostor in čas v folklori Krasa. Ljubljana: Znanstvena založba Filozofske fakultete.

_ 2010b. »Prostorska struktura vasi v ustnem izročilu, šegah in navadah na Krasu. « Traditiones: zbornik Inštituta za slovensko narodopisje 39 (2): 87-105.

Ilešič, S. 1950. Sistemi poljske razdelitve na Slovenskem. Ljubljana: SAZU.

Kačičnik Gabrič, A. 2004. "Gospostvo Brdo v luči Franciscejskega katastra.« Kronika 52 (2): 175-184.

Kolega, N. 2018. »Prostorska analiza prebivalstva in živinoreje na Primorskem na podlagi Franciscejskega katastra (1827)."V Preživetje in podjetnost: integrirana kmečka ekonomija na Slovenskem od srednjega veka do danes, ur. A. Panjek in Ž. Lazarević, 305-359. Koper: Založba Univerze na Primorskem.

Krahwinkler, H. 2004. . . . in loco qui dicitur Riziano ... Zbor v Rižani pri Kopru leta 804. Koper: Založba Annales.

Medvešček, P. 2015. Iz nevidne strani neba. Ljubljana: Založba Z R C.

Natek, M. 1979. »Pomen Franciscejskega katastra za agrarno-geografska proučevanja." Geografski vestnik 51:97-107.

Panjek, A. 1997. »Un contributo alla storia economica e sociale del Carso nel '500: presentazione di una fonte." Metodi e ricerche 16 (2): 41-56.

- 2002. Terra di confine: agricolture e traffici tra le alpi e l'Adriatico: la contea di Gorizia nel Seicento. Gorica: Edizioni della Laguna.

—. 2015a. "Kmečki odpor na Tolminskem: oris z opredelitvijo vsebinskih stebrov. "V Upor, nasilje in preživetje: slovenski in evropski primeri iz srednjega in novega veka, ur. F. Bianco in A. Panjek, 61-81. Koper: Založba Univerze na Primorskem.

- 2015b. Kulturna krajina in okolje Krasa: o rabi naravnih virov v zgodnjem novem veku. Koper: Založba Univerze na Primorskem.

- 2015/2016. „Opčina, zavod, podruštvo, mirišče: slovenski izrazi v 
devinskih dokumentih (Kras, 1562-1756).« Goriški letnik: zbornik Goriškega muzeja 39-40:111-121.

- 2016. "Pravda o spornem hramu: običaj ustne kupoprodaje nepremičnin med kmeti na Krasu (Tomaj, 1619-1620). Zgodovinski časopis 70 (3-4): 290-312.

—. 2018a. »Kruh naredi človeka: kdo je kdaj sit na primorskem podeželju v 17. in 18. stoletju. "V Lakote in pomanjkanje: slovenski primer, ur. M. Šorn, 25-41. Ljubljana: Inštitut za novejšo zgodovino.

- 2018b. "Statut in privilegiji komuna ali tabora Rihemberk (1556): avtoportret soseske pred izzivi ekonomskih, socialnih in okoljskih sprememb.« Goriški letnik: zbornik Goriškega muzeja 39-40:115-148.

Peršolja, J. 1997. »Rodiški komun. «V Rodik med Brkini in Krasom: zbornik ob 350. letnici cerkve, ur. M. Pregelj, 121-170. Koper: Ognjišče.

- 2009. Rodiški rodovi. Sežana: Kulturno društvo Vilenica.

Peršolja, J., in M. Pregelj. 1997. »Rodiška župnija. "V Rodik med Brkini in Krasom: zbornik ob 350. letnici cerkve, ur. M. Pregelj, 79-126. Koper: Ognjišče.

Pleterski, A. 1989. "Metoda povezave retrogradne analize katastra s pisanimi in arheološkimi viri (primer Blejskega kota).«Zgodovinski časopis 43 (2): 157-182.

- 2005. "De Sclavis autem unde dicitis: Slovani in Vlahi na ınikogaršnjem ‘ ozemlju istrskega zaledja."Acta Histriae 13 (1): 113-150.

—. 2011. Nevidna srednjeveška Evropa: župa Bled. Ljubljana: Založba ZRC.

Pregelj, M., ur. 1997. Rodik med Brkini in Krasom: zbornik ob 350. letnici cerkve. Koper: Ognjišče.

Premrl, B. 2004. »Kamnoseki Felicijani v luči arhivskih in epigrafskih virov.« Zbornik za umetnostno zgodovino 40:282-311.

Ratkajec, H. 2014. »Kraške skupnosti ob jadranski obali v Franciscejskem katastru. "Povijesni prilozi 33 (47): 207-228.

Ribnikar, P. 1982. "Zemljiški kataster kot vir za zgodovino.« Zgodovinski časopis $36(4):$ 321-337.

Scott, J. C. 1998. Seeing Like a State: How Certain Schemes to Improve the Human Condition Have Failed. New Haven, с T: Yale University Press.

Slapšak, B. 1997. »Starejša zgodovina Rodika.« V Rodik med Brkini in Krasom: zbornik ob 350. letnici cerkve, ur. M. Pregelj, 19-61. Koper: Ognjišče.

—. 1999. "Slovenski Kras v poznejši prazgodovini in v rimski dobi.« V Kras: pokrajina, življenje, ljudje, ur. A. Kranjc, 145-163. Ljubljana: Založba ZRC.

—. 2003. "O koncu prazgodovinskih skupnosti na Krasu.«Arheološki vestnik 54:243-257.

Vodopivec, P. 2011. „O Vačah pred velikim požarom leta 1934: Vače in okoliška naselja v gradivu Franciscejskega katastra.« Kronika 59 (3): 505-514. 
Zonabend, F. 1993. Dolgi spomin: časi in zgodovine na vasi. Ljubljana: Studia humanitatis.

Zupet, J. 1997. »Katapan Rodiške župnije iz leta 1885."V Rodik med Brkini in Krasom: zbornik ob 350. letnici cerkve, ur. M. Pregelj, 71-78. Koper: Ognjišče.

Žitko, S. 2005. »Objave in interpretacije listine Rižanskega placita v domačem in tujem zgodovinopisju.«Acta Histriae 13 (1): 151-165.

\section{Slika Rodika izpred dveh stoletij: vidno, navidezno in hipoteze med zgodovino in ljudskim izročilom}

Poglavje obravnava primorsko zgodovino podeželja skozi študijo primera $\mathrm{v}$ vasi Rodik. V prvem delu se osredotoča na gospodarstvo, družbo in okolje na začetku 19. stoletja, v drugem pa na preverjanje lokalnega ustnega izročila o nastanku in strukturi naselja v daljšem časovnem obdobju. Delo temelji na podatkih in informacijah Franciscejskega katastra, ki je znan in cenjen vir zlasti za zgodovinarje in geografe. Odlikuje ga izjemno bogastvo informacij, ki prvič v zgodovini tega območja zagotavljajo sistematičen in podroben vpogled na podlagi standardiziranih podatkov v kartografski, besedilni in številčni obliki. Zaradi tega je koristen tako za študije na mikroravni kot za obsežne regionalne analize. Njegova vrednost je tudi v tem, da je nastal v obdobju pred prehodom iz predindustrijske dobe $\mathrm{v}$ dobo industrializacije, in tako nudi sliko stanja v tej zgodovinski fazi. Prvotni cilj katastra opredeljuje tipologijo njegovih podatkov, ki je močno povezana s kmetijstvom. Kljub temu lahko v njem najdemo druge vrste informacij. Poleg tega, da na podlagi študije primera prispeva k raziskovanju zgodovine podeželja, prispevek preučuje tudi potenciale samega vira.

Opaziti je mogoče, da predstavniki lokalne skupnosti, ki so sodelovali pri izdelavi katastra, niso želeli poudariti pozitivnih vidikov svojega gospodarstva, saj je bil rezultat tega obdavčitev. Po drugi strani so uradniki poenostavljali lokalno realnost, da bi jo uvrstili v standardizirane kategorije, obenem pa so bili tujci v kmečki družbi in kulturi, zaradi česar so ignorirali lokalno znanje, prakse, značilnosti in vrednote.

Članek prikazuje, kako lahko v primeru študije na mikronivoju in z doslednim kritičnim pristopom okrepimo povednost vira $z$ vključevanjem informacij iz različnih katastrskih protokolov, obrazcev in zemljevidov. Na ta način se na površju pojavijo skrite značilnosti lokalne resničnosti in dobimo globlji, celovitejši vpogled. $V$ tem smislu prispevek razkriva meje med vidnim, nevidnim in zastrtim $v$ Franciscejskem katastru. $V$ tem primeru se je izkazalo, da so bili naravni viri (gozd, voda) bogatejši in oblike kmetovanja (intenzivnost, kolobarjenje) zapletenejše, kot poročajo posamezni dokumenti, ter da je bila skupnost v Rodiku manj kmečka od slike, ki so jo podali katastrski uradniki. Dodatno lahko opozorimo na prisotnost modernih prehrambnih in potrošnih pridelkov in izdelkov, kot so koruza, krom- 
pir in tobak. Na podlagi rezultatov prvega dela se $\mathrm{v}$ drugem delu poglavja z zgodovinopisnimi metodami preverja lokalno ustno izročilo o tem, kateri je bil najstarejši del vasi in kakšne so bile njene notranje delitve. S kombiniranjem analize posesti na najstarejšem delu obdelovalnih zemljišč (katera gospodinjstva so posedovala več prvotnih zemljišč) z uporabo poenostavljene različice retrogradne metode Andreja Pleterskega, kazalniki premoženja (struktura hiš, število domačih živali) iz Franciscejskega katastra ter na podlagi obstoječe zgodovinske, arheološke in etnografske literature avtor predlaga interpretacijo, po kateri je bila izvorna vas na desni oziroma severni strani glavne vaške ulice (slika 5).

V zaključku se vsekakor opozarja, da kljub vsaj navideznemu identificiranju treh prekrivajočih se možnih izvorov rodiške »obredne« delitve ne moremo povsem izključiti, da je nekdaj prišlo do kakega razkola znotraj skupnosti (na osnovi delitve med bogate in revne prebivalce ali med stanovalce starejšega in novejšega dela vasi, ali pa tudi ne), ki ga ne poznamo in čigar posledica je bila notranja razdeljenost. To bi bila tema za posebno raziskavo, če bi jo le pisni viri dopustili.

\section{A Picture of Rodik from Two Centuries Ago: The Visible, the Apparent and Some Hypotheses between History and folk Tradition}

The chapter addresses the rural history of Littoral Slovenia through a case study on the village of Rodik. In the first part it focuses on its economy, society and environment at the beginning of the 19th century, while in the second to verify the local oral tradition on the origin and structure of the settlement over a long period of time. The work is based on data and information from the Franziscean cadastre, which is a well-known and appreciated source especially for historians and geographers. It is distinguished by an extraordinary wealth of information that, for the first time in the history of this area, provides systematic and detailed insight based on standardized data in cartographic, textual and numerical form. This makes it useful for both micro-level studies and extensive regional analyses. Its value also lies in the fact that it originated in the transition period from pre-industrial to industrialization times, thus offering a picture of the situation at this historical phase. The original destination of the cadastre defines the typology of its information, which is strongly agriculture-related. Nevertheless, other kinds of information may be found. Apart from contributing to rural history research on a case study basis, the paper examines the potentials of the source itself.

It may be observed that the representatives of the local community involved in the creation of the cadastre were not interested in emphasizing the positive aspects of their economy, since the result was taxation. On the other hand, officials tended to simplify local reality in order to fit it into standardized categories, while being outsiders to the peasant society and culture, 
easily causing them to ignore local knowledge, practices, characteristics and values.

The article demonstrates how, in the case of a micro-level study and with a consistent critical approach, we can increase the source's expressiveness by integrating information from different cadastral protocols, forms and maps. This way, hidden features of local reality come to the surface and we obtain a deeper, more comprehensive insight. In this sense, the article reveals the boundaries between the visible, the virtual and the obscured in the Franziscean cadastre. In this particular case, it turns out that natural resources (woods, water) were richer and the forms of farming (intensity, crop rotation) more complex than individual documents reported, and that the community in Rodik was less peasant-like of the image given by the cadastre officials. We may additionally signal the presence of modern food and consumption items, such as maize, potatoes and tobacco.

Basing on the results of the first part, in the second part of the chapter historiographic methods are used to verify the local oral tradition on which was the oldest part of the village and what were its internal divisions. By combining the analysis of the property on the oldest part of the arable lands (which households had more of the original land) by using a simplified version of Pleterski's method, with wealth indicators (house structure, number of animals), taken from the Franziscean cadastre, and using the support of existing historical, archaeological and ethnographic literature, the author tends to demonstrate that the originary village was located on the right or the north side of the main village street (fig. 5).

In the closing remarks it is pointed out that, despite having seemingly identified as many as three overlapping possible sources of Rodik's »ritual« division (spatial divide, origin of the village, wealth divide), we cannot completely rule out that in the Rodik case there was once a split within the community (based on division between rich and poor or between residents of the older and newer part of the village, or not), which we do not know and which resulted in internal division. This would be a topic for special research if only written sources allowed it.

\section{Slika Rodika od prije dva stoljeća: vidljivo, prividno i hipoteze između povijesti i folklora}

Poglavlje se bavi poviješću ruralnog područja Primorske kroz studiju slučaja na primjeru sela Rodik. Prvi dio poglavlja usredotočen je na gospodarstvo, društvo i okoliš početkom 19. stoljeća, a drugi na provjeru lokalne usmene predaje o podrijetlu i strukturi naselja tijekom duljeg vremenskog razdoblja. Rad se temelji na podacima i informacijama pridobivenim iz Franjevačkog katastra, poznatog i cijenjenog izvora, osobito za povjesničare i geografe. Odlikuje se iznimnim bogatstvom informacija koje po prvi put u povijesti ovog prostora pružaju sustavni i detaljan uvid koji se temelji na standardiziranim podacima u kartografskom, tekstualnom i numeričkom obliku. Zbog 
toga je podjednako koristan kako za studije na mikro-razini, tako i za opsežne analize ovog prostora. Vrijednost ovog rada također leži u činjenici da je nastao u razdoblju prije prijelaza iz predindustrijskog razdoblja u razdoblje industrijalizacije i da nudi sliku stanja u ovoj povijesnoj fazi. Primarni cilj katastra određuje tipologiju njegovih podataka koja je u velikoj mjeri povezana s poljodjelstvom. Ipak, u njemu se mogu pronaći i druge vrste informacija. Osim što na temelju studije slučaja doprinosi proučavanju povijesti ovog ruralnog područja, ovaj rad istražuje i potencijale samog izvora.

Može se primijetiti da predstavnici lokalne zajednice koji su sudjelovali u izradi katastra nisu željeli isticati pozitivne aspekte svog gospodarstva čiji je krajnji rezultat bio oporezivanje. S druge pak strane, zbog nedovoljnog poznavanja seoskog društva i kulture, službenici su ignorirali znanja, prakse, značajke i vrijednosti lokalne stvarnosti i pojednostavnjivali stvarnu sliku lokalnog područja kako bi ga mogli svrstati u standardizirane kategorije.

Članak pokazuje kako, u slučaju studije na mikro-razini, dosljednim kritičkim pristupom i uključivanjem podataka iz različitih katastarskih protokola, obrazaca i zemljovida možemo povećati relevantnost izvora. Na taj način skrivene značajke lokalne stvarnosti izlaze na površinu i dobivamo dublji, sveobuhvatniji uvid. U tom smislu, ovaj rad uklanja granice između vidljivog, nevidljivog i prikrivenog u franjevačkom katastru. U ovom se slučaju pokazalo da su prirodni izvori (šuma, voda) bili bogatiji, a oblici poljodjelstva (intenzitet, raznolikost usjeva) složeniji nego što se prikazivalo u pojedinačnim dokumentima te da lokalna zajednica u Rodiku nije bila seoska zajednica u mjeri u kojoj su je prikazivali katastarski službenici. Osim toga, možemo skrenuti pozornost na prisutnost moderne prehrambene i potrošačke kulture i proizvoda poput kukuruza, krumpira i duhana.

$\mathrm{Na}$ temelju rezultata iz prvog dijela, u drugom dijelu poglavlja se historiografskim metodama provjerava lokalna usmena predaja o tome koji je bio najstariji dio sela i kakve su bile njegove unutarnje podjele. Kombinirajući analizu posjeda na najstarijem dijelu obrađenih površina zemljišta (od kojih su neka od njih bila u izvornom vlasništvu pojedinih kućanstava) s pojednostavljenom verzijom retrogradne metode Andreja Pleterskog, pokazateljima stanja imovine (struktura kuća, broj domaćih životinja) iz franjevačkog katastra i na temelju postojeće povijesne, arheološke i etnografske literature, autor predlaže interpretaciju prema kojoj je izvorno selo bilo locirano s desne ili sjeverne strane glavne seoske ulice (slika 5).

U zaključku se svakako napominje da unatoč barem očiglednoj identifikaciji tri preklapajuća moguća izvora »ritualne« podjele sela Rodik, ne može se u potpunosti isključiti da je nekada postojao raskol unutar zajednice (možda temeljem podjele na bogate i siromašne stanovnike ili na stariji i noviji dio sela), što mi ne znamo i što je rezultiralo unutarnjom razjedinjenošću zajednice. Kada bi to pisani izvori dopuštali, ovo bi mogla biti tema posebnog istraživanja. 